\title{
Are Insurance Companies Liable Under the Americans with Disabilities Act?
}

\author{
Jeffrey S. Manning $\dagger$
}

\section{TABLE OF CONTENTS}

Introduction

I. Insurance Regulation Under the ADA ..............................................614

II. The Meaning of the Public Accommodation Provision........................616

A. Interpreting the Scope of Section 302(a) ......................................617

1. Discrimination in Physical Access.........................................617

2. Discrimination in Providing Goods and Services ...................618

B. Why a Physical-Access Reading of Section 302(a) Is Wrong

1. Section 302(b)'s Definition of Section 302(a)'s Scope

a. Prohibited Ways of Discriminating...

b. Classes of People Covered Who Would Have No Protection Under the Physical-Access Reading

c. The Negative Implication of the Parts of Section 302(b) and Other Sections that Do Pertain to Physical Access

2. Listed Entities Incompatible with the Physical-Access Reading

3. The ADA's Stated General Purpose im Section 2(b) ............624

4. Legislative History on the Construction of Title III 625

5. The Parker Opinion

III. The Meaning of the Safe Harbor Provision, Section 501(c)

A. The Subterfuge Clause as the Basis of Requiring

Risk-Based Insurance Decisions: An Unsound Strategy

Copyright $\odot 2000$ California Law Review, Inc.

$\dagger \quad$ Law Clerk, Judge Irma S. Raker, Maryland Court of Appeals. J.D., School of Law, University of California, Berkeley (Boalt Hall); M.A., San Francisco State University; B.A., Oberlin College. My thanks to Arlene Mayerson, Guy Wallace, and Shawna Parks for their efforts in reviewing the manuscript; to my diligent editor, Alistair Newbern; and to Disability Rights Advocates, Oakland, California, for giving me my first opportunity to work on this issue, as a summer assistant. The piece is dedicated to my delightful future wife, Sheri F. Cartwright. 
B. The Concept of Underwriting and Classifying Risks as the Basis of Requiring Risk-Based Insurance Decisions:

A Better Solution .643

C. Actual or Reasonably Anticipated Experience: An Uncharted Issue . .647

Conclusion .650 


\title{
Are Insurance Companies Liable Under the Americans with Disabilities Act?
}

\author{
Jeffrey S. Manning
}

Federal courts have split on the question of the applicability of the Americans with Disabilities Act to insurance coverage decisions that insurance companies make on the basis of disability; they have similarly split on other issues pertaining to the scope of that Act's application. In deciding whether to read the Act as prohibiting discrimination in insurance decisions that are often crucial in the lives of people with disabilities, courts have faced two problems. First, where it prohibits discrimination in the equal enjoyment of the goods and services of places of public accommodation, the Act's area of concern may be limited to the ability of people with disabilities to gain physical access to facilities; or that area may extend to all forms of disability-based discrimination in the provision of goods and services. This Comment argues that the language and legislative history of the Act are consistent only with the latter view. Second, the provision limiting the Act's applicability to insurance may create an exemption for all insurance decisions; or it may protect only the ability of an insurance company to make an insurance decision to the disadvantage of an insured with a disability where actuarial data support the decision. This Comment argues that the ambiguous language of the limiting provision should be resolved in favor of the latter view. Legislative history and the broader background of the history of insurance discrimination law support this resolution. Consequently, the Act should be interpreted as prohibiting disability-based discrimination by insurance companies in selling insurance policies and as defining discrimination as making disability-based insurance decisions without the support of actuarial data. By accepting this interpretation, courts can help stop the pattern of judicial narrowing of the Act's application through inappropriately restrictive statutory construction.

\section{INTRODUCTION}

In recent years, federal courts have split on the questions of whether and when to hold an insurance coinpany liable under the Americans with Disabilities Act of $1990^{1}$ ("ADA" or "the Act") for inaking insurance decisions on the basis of an individual's disability. The cases that coinprise this

1. 42 U.S.C. $\$ \S 12101-12213$ (1994). 
split divide on two questions. First, what does Title $\mathrm{II}^{2}$ of the ADA, the section prohibiting discrimination by private businesses against customers with disabilities, mean when it forbids discrimination by a "place of public accommodation"? ${ }^{3}$ Is an insurance company that sells its policies over the phone or through the mail, never requiring a customer to visit its physical facilities, a place of public accommodation, such that it is covered by the Act? And second, what is the effect of the ADA's "safe harbor" provision, which excludes from ADA regulation the insurance practice of "underwriting risks"? Does this provision exempt insurance companies from the ADA altogether or only protect those decisions that are justified by actuarial data? It is settled law that Title I of the ADA applies to the practices of employers im providing group insurance to their employees, as Part I below explains. But the liability of insurance companies theinselves remains unsettled because of courts' differing answers to these two questions.

As the facts of the cases cited in this Comment indicate, the question of the ADA's regulation of insurance companies is crucially important to the lives of many people with disabilities. Disability-based insurance decisions have often cut off access to health care after two years for people disabled by mental illnesses, while benefits for physical illness would have continued until the insured reached age sixty-five. ${ }^{5}$ Such disability-based decisions have also resulted in the refusal to sell any disability insurance, even a policy excluding coverage of mental health expenses, to a person with a current history of treatinent for a mental health condition. ${ }^{6}$ An insurer has refused to sell property insurance to a landlord because the landlord rented his property to an organization that subleased to developmentally disabled tenants. ${ }^{7}$ An insurer has refused to sell a joint life insurance policy to a married couple because they suffered from depression and other mental health conditions. ${ }^{8}$ An insurance coinpany has charged double the usual rate for selling life insurance to a thirty-five-year-old man with a form of muscular dystrophy that was expected to reduce his life span by less than five years. ${ }^{9}$ And an insurer has refused to sell an insurance policy covering AIDS or AIDS-related conditions on the same terms as other illnesses, imposmg a lifetime benefits cap of $\$ 25,000$, coinpared to $\$ 1$ imillion for other conditions. ${ }^{10}$ These are only a few examples of the

\footnotetext{
2. Id. §§ 12181-12189.

3. Id. $\S 12182(\mathrm{a})$.

4. Id. $\$ 12201(\mathrm{c})$.

5. See, e.g., Erwin v. Northwestern Mut. Life Ins. Co., 999 F. Supp 1227, 1228 (S.D. Ind. 1998).

6. See Winslow v. IDS Life Ins. Co., 29 F. Supp. 2d 557, 558 (D. Minn. 1998).

7. See Wai v. Allstate Ins. Co., No. A.97-01551, 1999 WL 966284 (D.D.C. 1999).

8. See Palozzi v. Allstate Life Ins. Co., 998 F. Supp. 204, 205 (N.D.N.Y. 1998).

9. See Chabner v. United of Omaha Life Ins. Co., 994 F. Supp. 1185, 1187-88 (N.D. Cal. 1998).

10. See Doe v. Mutual of Omaha Ins. Co., 179 F.3d 557, 558 (7th Cir. 1999).
} 
myriad ways in which discrimination by insurance companies profoundly affects the health and lives of people with disabilities.

The first of the questions, examined in Part II of this Comment, has led to a debate among the circuits about whether the ADA's use of the phrase "place of public accommodation" implies that the real concern of Title III is not that disabled customers should have an equal ability to obtain the goods and services of private businesses, but only that they should have equal bodily access to the physical facilities in which private businesses - the "public accommodations" in question-are housed. Courts holding against disabled insurance customers take the position that unless the discrimination at issue was a customer's physical inability to get into an insurance office, there is no ADA violation. Courts ruling for disabled insurance customers hold that the word "place" implies no such limitation, and reason that differences in insurance coverage or pricing based on a customer's disability can violate the ADA.

Courts accepting the insurers' position on this question add a new weapon to the arsenal of conceptions that courts have sometimes used to narrow the scope of the ADA. This weapon, which emerges most clearly from the opimion of the Sixth Circuit in Parker v. Metropolitan Life Insurance Co., ${ }^{11}$ consists of a picture of disability discrimination as the absence of wheelchair ramps, Braille signs, and other simple, concrete impediments to the ability of people with certain easily identified disabilities to get around in the world. Prohibiting forms of discrimination that are more subtle, complex, or abstract, such as discrimination in the terms of insurance policies, and that therefore fall outside this paradigm, is rejected as contrary to common sense. The legal analysis typically follows this intuition. In this respect, the prodefense Title III insurance decisions resemble recent decisions of the United States Supreme Court, ${ }^{12}$ which chose to accept a narrow interpretation of the ADA's definition of disability primarily because it believed that the plaintiffs' broader one would include a counterintuitively large number of people within the ADA's protection. The Court decided that the definition of a person with a disability as one who has an impairment that "substantially limits one or more of the inajor life activities," or who has a record of such an impairment or is regarded as having such an impairment, ${ }^{13}$ should be read as including only those people who are substantially limited even while employing mitigating measures. ${ }^{14}$

11. 121 F.3d 1006 (6th Cir. 1997) (en banc).

12. See Sutton v. United Air Lines, 119 S. Ct. 2139 (1999); Murphy v. United Parcel Serv., 119 S. Ct. 2133 (1999).

13. 42 U.S.C. $\$ 12102(2)$ (1994).

14. See, e.g., Sutton, 119 S. Ct. at 2146. 
The courts' discussion of the second of the questions examined in this Comment, addressed in Part III below, puts an interesting spin on the familiar debate of whether insurance coinpanies may use in their underwriting certain classifications, such as race or sex, that would be considered discriminatory in other settings. Advocates for policy holders have argued that msurers should not be allowed to use such categories in setting rates, even if meinbers of different races and genders im fact present different statistical risks; insurers have argued the contrary. Policy holder advocates unsuccessfully sought legislation in Congress to eliminate the use of certain statistical categories. ${ }^{15}$ Nevertheless, they did achieve one victory against imsurers seeking to apply such categories when the Supreme Court held that a retireinent plan that paid lower inonthly benefits to women because they live longer than men violated Title VII of the Civil Rights Act of $1964 .{ }^{16}$ In Title III msurance cases, however, the parties assume a different stance: Insurers argue they should be allowed to charge disabled policy holders higher premiuins or to deny coverage altogether without statistical evidence of increased risk, while disabled policy holder plaintiffs seek to require such evidence to justify disability-based insurance decisions. Courts ruling for insurers have held that the safe harbor provision exempts "risk underwriting" froin ADA regulation and frees insurers to inake disability-based decisions in any manner. Those holding for disabled policy holders have found that the provision shields only traditional statistics-based practices, so that disability-based decisions not tied to actuarial data are subject to regulation under the ADA.

This Comment argues that courts holding for plaintiff policy holders are correct on both issues. On the ineaning of "places of public accommodation," attentive reading of the statute itself shows the decisions supporting a physical-access reading of Title III to be indefensible. On the statistical classification issue, though the statute's language is ambiguous, placing the provision in the context of the broader insurance classification controversy and reading its legislative history, leads to the conclusion that Congress intended to protect only statistics-based decisions.

It is important that the proplaintiff positions on these two unsettled issues ultimately prevail. Were courts to uniformly hold otherwise, insurers would be effectively exeinpt froin the ADA, placing the ADA's approach to msurance at odds with its general antidiscrimination policy. Absent state law to the contrary, insurance coinpanies would be free, alone among social actors, to discriminate arbitrarily and to any degree on the basis of

15. See Leah Wortham, Insurance Classification: Too Important to be Left to the Actuaries, 19 U. MICH J.L. REFORM 349, 364 n.59 (1986).

16. See Arizona Governing Comm. v. Norris, 463 U.S. 1973 (1983). 
disability. ${ }^{17}$ The uncertainty of the ultimate outcome of Title III's coverage of insurance policies is part of the larger uncertainty about the direction of judicial interpretation of the ADA. As discussed above, the Supreme Court has already accepted a narrow interpretation of the definition of disability. But it has also recently interpreted other aspects of the ADA in ways that reflect acceptance of the law's departure from older conceptions of disability discrimination and disability policy. ${ }^{18}$ The battle over Title III's coverage of insurance policies is thus part of the larger war that disabled litigants are fighting to realize the $\mathrm{ADA}$ 's potential as a path-breaking social policy tool. ${ }^{19}$

17. For a position opposite to the one taken in this Comment, see Luke A. Sobota, Does Title III of the Americans with Disabilities Act Regulate Insurance?, 66 U. CHI. L. REV. 243 (1999).

18. See Olmstead v. L.C., 119 S. Ct. 2176, 2186 (1999) (recognizing as discrimination under the ADA a state's failure to place mentally disabled plaintiffs in community-based care, even thongh this did not fall within the traditional conception of discrimination as disparate treatment of similarly situated individuals); Cleveland v. Policy Management Sys., 119 S. Ct. 1597, 1601 (1999) (reconciling conflict between plaintiff's claim to be totally disabled for purposes of Social Security Disability Insurance application with plaintiff's claim to be an otherwise qualified individual with a disability for purposes of her ADA suit, by recognizing that the Social Security Act's older, benefits-oriented approach to disability pohicy was relevantly different from the ADA's civil-rights approach).

19. At the time of this writing, researcl revealed the following set of cases on point. Two circuit courts have held for the insurer on the issue of the meaning of the phrase "place of public accommodation" in section 302(a) of the Act. See Doe v. Mutual of Omaha Ins. Co., 179 F.3d 557, 563 (7th Cir. 1999), cert. denied, _ U.S. _, 2000 WL 12573; Parker v. Metropolitan Life Ins. Co., 121 F.3d 1006, 1011 n.3 (6th Cir. 1997) (en banc), cert. denied, 118 S. Ct. 871 (1998) (holding that "Title III only covers physical places."). The Parker court declined to decide the issue of the safe harbor created by section 501(c). See Parker, 121 F.3d at 1013 n.7 (ruhing that "the safe harbor provision is ... not implicated" by the facts of the case). Earlier, the Sixth Circuit had already held, in a noninsurance case, that Title III applies only to discrimination involving physical access. See Stoutenborough v. National Football League, Inc., 59 F.3d 580, 583 (6th Cir. 1995). Another circuit has held for the insurer on both issues. See Ford v. Schering-Plough Corp., 145 F.3d 601, 610-11, 61214 (3d Cir. 1998), cert. denied, 119 S. Ct. 850 (1999).

Another circuit court has held for the disabled plaintiff on the section 302(a) issue only. See Carparts Distrib. Ctr., Inc. v. Automotive Wholesaler's Ass'n, 37 F.3d 12, 19 (1st Cir. 1994) (holding that "establishments of "public accommodation"" are not "limited to actual physical structures"). The opimion does not address the safe harbor issue. Section 501 (c) is mentioned only as "a good example of [the] aunbiguities" in the ADA. Id. at 20.

Seven district court cases hold that Title III covers insurance practices, ruling in favor of plaintiffs with disahilities on both the section 302(a) issue and the section 501(c) issue. See Winslow v. IDS Life Ins. Co., 29 F. Supp. 2d 557, 562-63 (D. Minn. 1998); Chabner v. United of Omaha Life Ins. Co., 994 F. Supp. 1185, 1190-91 (N.D. Cal. 1998); Cloutier v. Prudential Ins. Co. of Am., 964 F. Supp. 299, 302, 303-04 (N.D. Cal. 1997); World Ins. Co. v. Branch, 966 F. Supp. 1203, 1207-08 (N.D. Ga. 1997); Kotev v. First Colony Life Ins. Co., 927 F. Supp. 1316, 1323 (C.D. Cal. 1996); Doukas v. Metropohtan Life Ins. Co., 950 F. Supp 422, 427, 431-32 (D.N.H. 1996); Baker v. Hartford Life Ins. Co., No. 94 C 4416, 1995 WL 573430, at *3-*4 (N.D. IIl. Sept. 28, 1995). Two district courts in insurance cases adopted the plaintiffs' view on the section 302(a) issue alone, omitting the section 501 (c) issue from their discussions. See Wai v. Allstate Ins. Co., No. A.97-01551, 1999 WL 966284, at *7 (D.D.C. 1999); Conners v. Maine Med. Ctr., 42 F. Supp. 2d 34, 46 (D. Maine 1999).

Also, two district courts ruled in noninsurance cases on the section 302(a) issue only, holding that the coverage of Title III is not limited to access to physical places. See Shultz v. Heniet Youth Pony League, Inc., 943 F. Supp. 1222, 1225 (C.D. Cal. 1996); Sharrow v. Bailey, 910 F. Supp. 187, 192 (M.D. Pa. 1995). One district court adopted the plaintiffs' theory requiring an actuarial basis under 
I

\section{INSURANCE REgULATION UNDER THE ADA}

The ADA's coverage of insurance as a service of a public accommodation differs from its coverage of insurance as a benefit of employment. It is useful to explain this difference in order to indicate what subject matter this Comment does and does not cover, and also to show that the ability to sue an employer for discrimination in the provision of insurance as a benefit of employment does not, in many cases, provide a remedy to a discriminatee. The ADA describes itself in its caption as "[a]n Act [t]o establish a clear and comprehensive prohibition of discrimination on the basis of disability." ${ }^{20}$ This promise of broad regulation is then carried out in the Act's substantive titles: Title $\mathbb{P}^{1}$ prohibits discrimination in employment, Title $\mathrm{I}^{22}$ in government services, and Title $\mathrm{II}^{23}$ in "public accommodations and services operated by private entities." ${ }^{24}$ Because its approach is thus so sweeping and holistic, the ADA was hailed after its passage in 1990 as "the most innovative and far-reaching federal civil rights legislation-ever-on behalf of disabled persons" ${ }^{\text {"25 }}$ and as "a historic landmark in the civil rights movement.".26

section 501(c), although it ultimately held for the defendant. See Palozzi v. Allstate Life Ins. Co, 998 F. Supp. 204, 207-08 (N.D.N.Y. 1998).

One district court aecepted the defendant's view on both the section 302(a) issue and the section 501(c) issue. See Leonard F. v. Israel Discount Bank, 967 F. Supp. 802, 804-06 (S.D.N.Y. 1997). Three others held for an insurer on the section 302(a) issue only. See Fitts v. Federal Nat'l Mortgage Ass'n, 44 F. Supp. 2d 317, 324 (D.D.C. 1999); Palozzi, 998 F. Supp. at 206; Erwin v. Northwestern Mut. Life Ins. Co., 999 F. Supp. 1227, 1233 (S.D. Ind. 1998); see also Pappas v. Bethesda Hosp Ass'n, 861 F. Supp. 616, 620 (S.D. Ohio 1994). One district court adopted the defense position in a noninsurance case on the section 302(a) issue only. See Brown v. 1995 Tenet ParaAmerica Bicycle Challenge, 959 F. Supp. 496, 498 (N.D. III. 1997).

In summary, the Third Circuit has held for defendants on the section 501(c) issue. The section 302(a) issue has produced a split between the Third, Sixth, and Seventh Circuits on the defense side, and the First Circuit on the plaintiff side. District courts cases go eleven to five for the plaintiffs' theory on the section 302(a) issue, and eight to one for the plaintiffs' theory on the section 501(c) issue.

Other cases have decided section 501(c) issues in the context of employee benefits under Title I. 1 have not tried to deal with these because they are coinplicated, in ways not relevant to suits against insurers, by the EEOC Interin Guidance on Application of ADA to Health Insurance, reprinted in 1993 Daily Lab. Rep. (BNA) No. 109, at D22 (June 9, 1993).

20. Pub. L. No. 101-336, 104 Stat. 327, 327 (1990).

21. 42 U.S.C. $\S \S 12111-12117$ (1994).

22. Id. $\S \S 12131-12165$.

23. Id. $\$ \S 12181-12189$.

24. The quoted language is the heading of Title III in the session laws. See Pub. L. No. 101-336, 104 Stat. 327, 353. In addition, Title IV, 47 U.S.C. $\$ \$ 225,611$ (1994), contains certain regulations for telecommunications providers, and Title V, 42 U.S.C. $\$ \S 12201-12213$, contains "miscellancous provisions."

25. Michael L. Perlin, The ADA and Persons with Mental Disabilities: Can Sanist Attitudes Be Undone?, 8 J.L. \& HeALTh 15, 15 (1994).

26. John W. Parry, Mental Disabilities Under the ADA: A Difficult Path to Follow, 17 MENTAL \& Physical Disability L. REP. 100, 100 (1993). 
It is well established that the ADA covers insurance as a benefit of employment. ${ }^{27}$ Title I comprehensively prohibits discrimination "in regard to job application procedures, the hiring, advancennent, or discharge of einployees, employee compensation, job training, and other terms, conditions, and privileges of employment."28 The U.S. Equal Einployment Opportunity Commission has issued regulations defining discrimination im employee health insurance plans. ${ }^{29}$ The answer to the question whether an insured can sue his employer for discrimination in insurance under the ADA is thus clearly yes. There is always someone-the employer-to sue when an enıployee has experienced discrimination in her employee benefit insurance.

The answer to whether an insured can sue his insurance company under the ADA, however, is less clear. Section 302(a), the general antidiscrimination provision of Title $\mathrm{III}$, provides that "[n]o individual shall be discriminated against on the basis of disability in the full and equal enjoyment of the goods, services, facilities, privileges, advantages or accommodations of any place of public accommodation." 30 Plaintiffs who have purchased insurance directly from insurance companies, ${ }^{31}$ as well as plaintiffs who receive insurance through their jobs, ${ }^{32}$ have sued insurance companies under this provision.

In both kinds of cases courts must first decide whether plaintiffs have availed themselves of a "service of a place of public accommodation." As Part II explains, some courts have einphasized the statute's use of the word "service" and held for plaintiffs on the ground that insurance, however obtained, is a service. Others have einphasized the use of the term "place" and held for defendants on the ground that insureds who gain access to insurance policies by phone or mail or through employers have never sought access to a place of public accommodation. The latter position thus treats Title III as primarily a prohibition on discrimination with respect to getting into buildings or otherwise obtaining bodily access to goods and services of private busmesses.

Next, courts must consider whether, even if covered by section 302(a), insurance companies are immunized from suit by the "safe harbor"

27. See, e.g., Ford v. Schering-Plough Corp., 145 F.3d 601, 605-06, 608 (3d Cir. 1998) (acknowledging the "explicit rights created by Title $\Gamma$ ' to be free of discrimination by an employer regarding fringe benefits of employment, even though ultimately rejecting the particular claim before the court on the ground that the $\mathrm{ADA}$ does not protect against discrimination between those with different types of disabilities, but only between the disabled and the nondisabled).

28. 42 U.S.C. $\$ 12112$ (a).

29. See EEOC Interim Guidance on Application of ADA to Health Insnrance, supra note 19, at D22.

30. 42 U.S.C. $\$ 12182(a)$.

31. See, e.g., Chabner v. United of Omaha Life Ins. Co., 994 F. Supp. 1185 (N.D. Cal. 1998).

32. See, e.g., Ford, 145 F.3d at 601. 
provision of section 501(c). ${ }^{33}$ This section provides that the Act "shall not be construed to prohibit or restrict ... an insurer ... from underwriting risks, classifying risks, or administering such risks that are based on or not inconsistent with State law." ${ }^{34}$ It then creates an exception to this language, providing that it "shall not be used as a subterfuge to evade the purposes of [Titles] I and III." 35 Thus, courts must address what sort of safe harbor this section creates for insurers and what constitutes using the section as a subterfuge.

For those who have bought insurance directly from an insurer, the answers to these two questions determine whether they have anyone to sue when there has been disability discrimination in the determination of the cost or coverage of their insurance policy; unlike those covered by employee benefit insurance, there is no defendant available to thein other than the insurance company. For insurance companies, the stakes are whether they owe ADA liability to any kind of insured, since a defendant's holding on either question shields insurers coinpletely from their direct customers and their eniployee-benefit customers alike.

\section{II}

\section{The Meaning of the Public Accommodation Provision}

Courts divide between those that read "place" in section 302(a) as a limit upon "goods, services, facilities, privileges, advantages or accommodations," and those that do not. Does the section prohibit discrimination only where the provision of goods or services has a connection of some specific kind with a "place," or does it prohibit discrimination in all provision of goods and services? One court explained the source of this problem as follows:

Part of the confusion that exists in this case stems from Congress' use of the term "public accommodation." This term harks back to the public accommodations language in the Civil Rights Act of 1964 and other early civil rights legislation, statutes designed to afford all persons with physical access to private establishments. Conceptually, the idea of access to places of public accommodation is very different from the idea of discrimination in the content of goods and services. Yet, rather than clearly stating its intention to write a broader reaching statute, the drafters have smiply grafted "goods and services" language onto "public accommodation" terminology. ${ }^{36}$

\footnotetext{
33. 42 U.S.C. \$ 12201(c).

34. Id.

35. Id.

36. Parker v. Metropolitan Life Ins. Co., 99 F.3d 181, 187 n.1 (6th Cir. 1996), rev'd, 121 F.3d 1006 (6th Cir. 1997) (en banc).
} 
Defendants have raised the issue of the meaning of discrimination $\mathrm{m}$ the provision of goods and services of a place of public accommodation in nearly every Title III insurance case that has resulted in a published opinion. ${ }^{37}$

\section{A. Interpreting the Scope of Section 302(a)}

\section{Discrimination in Physical Access}

The universe of decisions relevant to whether sectiou 302(a) excludes insurers from the ADA consists of five circuit court cases (from four circuits) and sixteen district court cases from twelve districts. ${ }^{38}$ The view adopted by three of the four circuits and five of the sixteen district courts that have decided the issue ${ }^{39}$ is that the section's "place of public accommodation" language prohibits discrimination only in what is variously described as "physical access," discrimination based on "physical ability to make use" services of public accommodations. These cases express the view that the purpose of Title III is to insure that people with disabilities can get into the buildings in which goods and services are offered (so that ramps and elevators must be provided for wheelchair users), and perhaps also read signs (so that they inust be provided in Braille) and use information provided in oral form (so that sign language interpretation must be provided) and so on. On the strength of the idea that "place" signifies something physical, these courts often say that their interpretation follows from the plain meaning of section 302(a). For instance, the court in Pappas $v$. Bethesda Hospital Ass'n stated that it was deciding the section 302(a) question on the basis of the "ordinary, common meaning' of the words in the statute." ${ }^{\text {43 }}$ It theu went on to say that because "[t]he statute provides examples of public accommodations, all of which are 'places' within the plain meaning of that word," im Title III to physical places, ${ }^{45}$ Title III must not cover any discrimination that "has nothing to do with an inability to make physical use of the services of a place of public accommodation." ${ }^{.46}$

37. See sources cited supra note 19.

38. See id.

39. See id.

40. Parker, 121 F.3d at 1008.

41. Id. at 1011 n.3.

42. Pappas v. Bethesda Hosp. Ass'n, 861 F. Supp. 616, 620 (S.D. Ohio 1994); see also Parker v. Metropolitan Life Ins. Co., 875 F. Supp. 1321, 1328 (W.D. Tenn. 1995).

43. Pappas, 861 F. Supp. at 620 (quoting United States v. Ransbottom, 914 F.2d 743, 745 (6th Cir. 1990), cert. denied, 498 U.S. 971 (1990)).

44. Pappas, 861 F. Supp. at 620.

45. See id.

46. Id. 


\section{Discrimination in Providing Goods and Services}

The remaining decisions hold that there is no limitation in section 302(a) to physical access. ${ }^{47}$ In Carparts Distribution Center v. Automotive Wholesaler's Ass' $n{ }^{48}$ the First Circuit held that to

limit the application of Title III to physical structures which persons must enter to obtain goods and services would run afoul of the purposes of the ADA and would severely frustrate Congress's intent that individuals with disabilities fully enjoy the goods, services, privileges, and advantages, available indiscriminately to other members of the general public. ${ }^{49}$

These courts reject the notion that section 302(a)'s prohibition of discrimination in the "enjoyment of the goods [and] services ... of any place of public accommodation"s0 is limited to forms of discrimination affecting a person's ability to get into a building where goods or services are available. Rather, they consider that Title III simply targets discrimination in the provision of goods and services by a place of public accommodation.

\section{B. Why a Physical-Access Reading of Section 302(a) Is Wrong}

The physical-access position is unsupported by the language of the ADA. To ban discrimination " $m$ the full and equal enjoyment of the goods [and] services ... of any place of public accommodation"s1 is to say nothmg in particular about "physical ability to make use." The "ability to make use" language is wholly court created, as some decisions have recognized, noting the absence of any reference to "physical access" in the statute. ${ }^{52}$ Moreover, despite some courts' assertions that "physical ability to make use" belongs to the "plain meaning" of Title $\mathrm{III},{ }^{53}$ this notion conflicts with large tracts of the statute's language. I examine these parts of the statute under three headings: (1) the overall structure and specific provisions of section 302(b), ${ }^{54}$ which offers authoritative interpretation of section 302 (a); (2) the list of entities in section 301(7), ${ }^{55}$ including some whose coverage is inconsistent with a physical-access reading; and (3) the $\mathrm{ADA}^{\prime}$ 's stated purpose ${ }^{56}$ of eliminating disability discrimination from

47. See sources cited supra note 19.

48. 37 F.3d 12 (1st Cir. 1994).

49. Id. at 20 .

50. 42 U.S.C. $§ 12182(a)$ (1994).

51. Id.

52. See, e.g., Cloutier v. Prudential Ins. Co. of Am., 964 F. Supp. 299, 302 (N.D. Cal. 1997); Kotev v. First Colony Life Ins. Co., 927 F. Supp. 1316, 1321 (C.D. Cal. 1996).

53. Stoutenborough v. National Football League, Inc., 59 F.3d 580, 582 (6th Cir. 1995); Leonard F. v. Israel Discount Bank, 967 F. Supp. 802, 804 (S.D.N.Y. 1997); Pappas v. Bethesda Hosp. Ass'n, 861 F. Supp. 616,620 (S.D. Ohio 1994).

54. 42 U.S.C. $\$ 12182(b)$.

55. Id. $\S 12181(7)$.

56. See id. \$12101(b). 
American life generally. Courts have recognized a few of these particular provisions as conflicting with the physical-access reading of section 302(a), but they generally have not recognized Title III's design as intendning to cover a wide variety of forms of discrimination, with discrimination through physical barriers as only one of these forms. ${ }^{57}$ After analyzing the ADA's language, I discuss the legislative history of Title III to show that Congress intended Title III to prohibit discrimination in the provision of goods and services generally, not only where the discrimination takes the form of a lack of physical access. Finally, I close this Part with a detailed critique of the en banc opinion in Parker v. Metropolitan Life Insurance Co. ${ }^{58}$ which contains by far the niost detailed defense of the physicalaccess reading of section 302(a).

\section{Section 302(b)'s Definition of Section 302(a)'s Scope}

Section 302(b) provides a detailed explanation of what section 302(a) prohibits. This explanation is broken down into "general" and "specific" prohibitions, sone of which pertain to physical access, and sone of which do not. A physical-access reading of Title III would seem simply to ignore the latter group of prohibitions, which I now discuss in detail. Roughly the first half of section 302(b) sets out prohibitions that have nothing in particular to do with physical impediments to access. Rather, two analytically distinct types of prohibition appear: prohibitions of certain ways of discriminating and prohibitions of discrimination against certain kinds of people.

\section{a. Prohibited Ways of Discriminating}

Sections 302(b)(1)(A)(i)-(iii) ${ }^{59}$ define three types of practice as discriminatory: denying participation in the benefits of ${ }^{60}$ providing an unequal benefit of ${ }^{61}$ or unnecessarily providing a separate benefit of ${ }^{62}$ a good or service on the basis of disability. Each of these provisions could be violated without denying the discriminatee physical access to a facility, because participation in the benefit of a good or service could be denied, or provided unequally or separately after the discriminatee had gained access to the facility. For instance, a wheelchair user could enter the facility via a ranp, only to find that the facility refuses to serve wheelchair users (thus denying the benefit), provides thein inferior service (thus providing an

57. See generally, e.g., Chabner v. United of Omaha Life Ins. Co., 994 F. Supp. 1185 (N.D. Cal. 1998).

58. 121 F.3d 1006 (6th Cir. 1997) (en banc).

59. 42 U.S.C. $\$ 12182(\mathrm{~b})(\mathrm{I})(\mathrm{A})(\mathrm{i})$-(iii).

60. See id. $\S 12182(\mathrm{~b})(\mathrm{l})(\mathrm{A})(\mathrm{i})$.

61. See id $\$ 12182(\mathrm{~b})(1)(\mathrm{A})(\mathrm{ii})$.

62. See id. \$12182(b)(1)(A)(iii). 
unequal benefit), or serves them in a separate room from nonwheelchair users (thus providing a separate benefit).

Sections $302(b)(1)(B)$ through $(D)^{63}$ continue in the same vein. Goods and services must be provided in "the most integrated setting appropriate;",64 people with disabilities must be permitted to participate in integrated programs or activities even if segregated ones are offered; ${ }^{65}$ and covered entities must not use "standards or criteria or methods of administration" ${ }^{\prime 66}$ that have discriminatory effects. There is, again, no reason to suppose that violations of these provisions are discriminatory only if they happen to involve denials of physical access. In the case of an oral presentation in a classroom, for instance, a place of public accommodation might msist that deaf people receive the presentation in a separate room, on the ground that sign language imterpreters will distract hearing members of the audience. This would be to offer a service in a setting less integrated than it could be, but it would not involve a denial of physical access to a good or service.

By the most natural interpretation, the phrase "standards or methods of administration" signifies policies that result im discrimination regarding the provision of goods and services, rather than im physical obstacles. For instance, a provider of classroom instruction might prohibit wheelchair users, or more than a certain number of wheelchair users, from bringing their wheelchairs into a classroom on the basis of a standard purportedly based on safety. This standard might have nothing to do with physical access-there could be plenty of room for the wheelchairs-but should still be the basis of a prima facie case of discrimination under Title III. ${ }^{67}$

Section 302(b)(2)(A) defines "discrimination" as used in section 302(a) to include:

the imposition or application of eligibility criteria that screen out or tend to screen out an individual with a disability or any class of individuals with disabilities from fully and equally enjoying any goods, services, facilities, privileges, advantages or accommodations, unless such criteria can be shown to be necessary for the provision of the goods, services, facilities, privileges, advantages, or accomniodations being offered ....68

This language is naturally read as prohibiting a disability-based definition of people eligible for receipt of a good or service. It would be most awkward to think of an eligibihty criterion as something that mipedes physical

\footnotetext{
63. Id. $\S 12182(\mathrm{~b})(1)(\mathrm{B})-(\mathrm{D})$.

64. Id. $\S 12182(\mathrm{~b})(1)(\mathrm{B})$.

65. See id. $\$ 12182(\mathrm{~b})(1)(\mathrm{C})$.

66. Id. $\$ 12182(\mathrm{~b})(1)(\mathrm{D})$.

67. It could also be permissible under a defense, of course, but the question here is whether a claim under Title III can be stated in the first place. See, e.g., id. $\$ 12183$ ("direct threat" defense).

68. Id. $\$ 12182(\mathrm{~b})(2)(\mathrm{A})(\mathrm{i})$ (emphasis added).
} 
access. A shoe store, for example, that refuses to serve deaf customers (using ability to hear as an eligibility criterion) would surely violate this subsection, even though those customers would be able to enter the store.

Section 302(b)(2)(A) next defines discrimination under section 302(a) as including:

a failure to inake reasonable modifications in policies, practices, or procedures, when such modifications are necessary to afford such goods, services ... to individuals with disabilities unless the entity can deinonstrate that making such inodifications would fundamentally alter the nature of such goods, [or] services . . . ${ }^{69}$

Discriminatory policies, like discriminatory eligibility criteria, have no particular connection with physical ability to make use of goods or services. A discriminatory policy could be a policy that demes services to people with disabilities despite the absence of a physical barrier. Soine courts have acknowledged this implication of section 302(b)(2)(A)(ii). ${ }^{70}$

\section{b. Classes of People Covered Who Would Have No Protection Under the Physical-Access Reading}

Section 302(b)(1)(E) expressly prohibits discrimination against certain classes of persons who would not be protected by a rule agamst inaccessible structures alone, providing that

[i]t shall be discriminatory to exclude or otherwise deny equal goods, services, facilities, privileges, advantages, accommodations, or other opportunities to an individual or entity because of the known disability of an individual with whoin the individual or entity is known to have a relationship or association. ${ }^{71}$

One court has observed that under the physical-access reading of Title III's prohibitions, the victims of association discrimination under this subsection would have a cause of action only if an entity "took affirmative steps to block such persons' physical access,"72 since victims of association discrimination would not have a disability tending to inhibit their physical access. The court's understated remark on this consequence is that it would be "anomalous."73 The prohibition of association discrimination makes sense only as a measure directed against discriminatory attitudes; because its victims have no disability themselves, the notion of physical inability to inake use has no application to them. To read Title III as prohibiting only

69. Id. $\$ 12182(\mathrm{~b})(2)(\mathrm{A})(\mathrm{ii})$ (emphasis added).

70. See, e.g., Chabner v. Umited of Omaha Life Ins. Co., 994 F. Supp 1185, 1190 (N.D. Cal. 1998); Cloutier v. Prudential Ins. Co. of Am., 964 F. Supp. 299, 302 (N.D. Cal. 1997).

71. 42 U.S.C. $\$ 12182(b)(1)(E)$.

72. Kotev v. First Colony Life Ins. Co., 927 F. Supp. 1316, 1322 (C.D. Cal. 1996).

73. Id. 
discrimination though physical inaccessibility would thus essentially render the association discrimination provision a nullity.

This subsection's logic is parallel to that of the ADA's general definition of covered individuals. The "definitions" section of the ADA, which applies to all of its titles, provides that the term "disability" includes mental disability, a record of a disability even in the absence of any present disability, and being incorrectly regarded as having a disability ${ }^{74}$ None of these classes of people would be protected by a rule recognizing a Title III cause of action only where the plaintiff has been physically unable to make use of a facility. It seems unlikely that Congress intended to exclude all these groups from the protection of Title III, including them only in the other titles. Congress would have had to intend that the exclusion be imferred from the use of the word "place," a roundabout way to achieve a legislative goal at odds with the rest of the statute. Congress's "clear and comprehensive mandate for the elimination" of disability discrimination ${ }^{75}$ includes those with mental disabilities, those with a record of a disability, and those regarded as having a disability. Courts should not defeat Congress's intent with respect to these provisions by means of a narrow reading. The physical-access reading of section 302(a) implies an especially dramatic exclusion of those with mental disabilities from the coverage of Title III. This is particularly so in light of the inclusion of people with mental disabilities im Congress's estimate of forty-three million people with disabilities. This estimate is included in the "findings" section of the ADA, ${ }^{76}$ and the Supreme Court relied on it in its recent definition-ofdisability cases. ${ }^{77}$

\section{c. The Negative Implication of the Parts of Section 302(b) and Other Sections that Do Pertain to Physical Access}

Section 302(b) does prohibit discrimination through impediments to physical access, but only in provisions created expressly for that purpose. Section 302(b)(2)(A)(iv) provides that "a failure to remove architectural barriers"78 constitutes discrimination under section 302(a). Section 302(b)(2)(B) consists of requirements, mostly pertaining to physical access, imposed on providers of public transportation. ${ }^{79}$ In addition, sections 303 to 306 deal extensively and thoroughly with physical barriers in new, remodeled, and existing buildings and public transit vehicles. ${ }^{80}$ The coexistence in Title III of provisions that do address physical access

\footnotetext{
74. See 42 U.S.C. § 12102(2).

75. Id. $\S 12101(b)(1)$.

76. See id. \$12101(a)(1).

77. See Sutton v. United Air Lines, 119 S. Ct. 2139, 2147 (1999).

78. 42 U.S.C. $\S 12182(\mathrm{~b})(2)(\mathrm{A})(\mathrm{iv})$.

79. See id. \$12182(b)(2)(B).

80. See id. §§ 12183-12186.
} 
specifically and those that have nothing in particular to do with physical access indicates that the statute contemplates those forms of discrimination that limit physical access as well as those that do not.

The existence of provisions specifically pertaining to impediments to physical access means that the physical-access-only interpretation of Title III renders superfluous those provisions not specifically pertaining to physical access. Such an interpretation violates the principle of statutory construction that courts should construe statutes to "avoid rendering superfluous any parts thereof."'"1 At least two cases rejecting the physicalaccess reading of Title III have made this observation and quoted this language. $^{82}$

\section{Listed Entities Incompatible with the Physical-Access Reading}

Section 301(7) is a list of fifty-six entities ranging" from "bowling alley" to "adoption agency" that are "considered public accommodations for purposes of this [title]." example noted by the First Circuit in Carparts to be an especially strong mdication that the statute does not support a physical-access imterpretation. "By mcluding 'travel service' among the list of services considered 'public accommodations," the First Circuit noted, "Congress clearly contemplated that 'service establishments' include providers of services which do not require a person to physically enter an actual physical structure," since travel services conduct much of their busmess by telephone and mail ${ }^{85}$ The same argument applies to several other listed entities, including "other sales or rental establishinent," "bank," "office of an accountant or lawyer," "imsurance office," and "other service establishınent." $\$ 86$

The reasoning of Carparts is thus that it is arbitrary to take physical presence as the only way of atteinpting to avail oneself of a service covered by Title III. In the case of msurance, the fact that "insurance office" is a listed entity is enough by itself, under this logic, to bring insurance policies within Title III. A Title III plaintiff who is treated in a discriminatory manner when trymg to buy msurance by mail, or through an employment relationship, from an imsurance company's office is im precisely the same position as one who was refused adimission to the insurance coinpany's office. Thus, to avoid distinctions that seem arbitrary, the ineans of

81. Astoria Fed. Sav. \& Loan Ass'n v. Solimino, 501 U.S. 104, 112 (1991) (citing United States v. Menasche, 348 U.S. 528, 538-39 (1955)).

82. See Chabner v. United of Omaha Life Ins. Co., 994 F. Supp. 1185 (N.D. Cal. 1998); Cloutier v. Prudential Ins. Co. of Am., 964 F. Supp. 299, 302 (N.D. Cal. 1997).

83. 42 U.S.C. $\$ 12181(7)$.

84. Id. \& $12181(7)(\mathrm{F})$.

85. Carparts Distrib. Ctr., Inc. v. Automotive Wholesaler's Ass'n, 37 F.3d 12, 19 (1st Cir. 1994) (quoting 42 U.S.C. $\$ 12181(7)(F)$ ).

86. 42 U.S.C. $\S 12181(7)(\mathrm{E})-(\mathrm{F})$. 
doing business with listed entities is regarded as irrelevant. Again, where Congress's goal is to eliminate disability discrimination, ${ }^{87}$ it is implausible to believe that Congress intended to make the outcomes of individual cases depend on whether the discriminatory conduct did or did not involve the physical ability to enter a building.

\section{The ADA's Stated General Purpose in Section 2(b)}

As at least one district court has observed, the proposition that Title III only prohibits discrimination in physical access also "runs counter to the broadly stated purpose" and comprehensive national inandate for the elimination of discrimination against individuals with disabilities," ${ }^{, 89}$ and "to invoke the sweep of congressional authority ... in order to address the inajor areas of discrimination faced day-to-day by people with disabilities." able that, having spoken broadly of "the elimination" of disability discrimination "in its inajor areas" in the prefatory section of the statute, Congress meant to address in Title III only the single area of discrimination through physical barriers to access to structures. Title III is not a narrowly focused piece of legislation. It reaches, in its terms, huge areas of our collective life. Therefore, to conclude that Title III protects from discrimination persons attempting to enter a building to purchase services, but not persons purchasing services without entering a building, would be "an absurd result," as the First Circuit held in Carparts. ${ }^{91}$

Courts that choose the narrow interpretation of the ADA's public accommodations language, like courts that choose the narrower of two available options in reading other provisions of the $\mathrm{ADA},{ }^{92}$ forget the consensus that existed across the political spectruin in Congress at the time of the ADA's passage. Strong rhetoric representing the new law as revolutionary in purpose and encompassing in scope issued from both sides of the aisle. In his speech following the Senate's ninety-one to six roll call vote on the conference report that finalized the ADA's language, Senator Robert Dole stated:

I have supported the ADA because I believe it is a just and fair bill which will bring equality to the lives of all Anericans with disabilities. Our inessage to America today is that inequality and prejudice will not [sic] longer be tolerated. Our message to people with disabilities is that your time has come.

\footnotetext{
87. See id. § 12101(b)(1).

88. Kotev v. First Colony Life Ins. Co., 927 F. Supp. 1316, 1321 (C.D. Cal. 1996).

89. 42 U.S.C. $\$ 12101(b)(1)$.

90. Id. § 12101(b)(4).

91. Carparts Distrib. Ctr., Inc. v. Automotive Wholesaler's Ass'n, 37 F.3d 12, 19 (1st Cir. 1994).

92. See supra note 19 and accompanying text.
} 
We have included in this legislation all people with all disabilities, no matter how misunderstood because that is what this bill is about-replacing misunderstanding with understanding. We have not said that you have to employ a person in a job they really cannot do, or in a setting where they will pose a danger to the health or safety of other people. What we have said is that these decisions must be inade about imdividuals, not groups and must be based ou facts, not fears.

We have had a patch work quilt up until now-an inconsistent and pieceineal approach to disability policy. Today we move to embrace the most comprehensive civil rights legislation our Nation has ever seen. Today we move to put old stereotypes and attitudes behind us-where they belong. ${ }^{93}$

To view the public accommodations language of the ADA as referring only to physical ability to gain access to structures is to ignore the spirit in which Congress approved that language and to disregard the words of the ADA's purpose section, ${ }^{94}$ in which Congress captured that spirit.

\section{Legislative History on the Construction of Title III}

The ADA's legislative history stresses the breadth of its antidiscrimination provisions, and the First Circuit in Carparts read Title III in the light of this evidence of congressional intent. Quoting the report of the House Committee on Education and Labor, the court held that the "purpose of Title III of the ADA is 'to bring individuals with disabilities mto the economic and social inainstream of American life ... in a clear, balanced, and reasonable manner." Citing the report of the Senate Committee on Labor and Human Resources, the court stated that when Congress drafted Title III, it "intended that people with disabilities have equal access to the array of goods and services offered by private establishments and inade available to those who do not have disabilities." 96 Therefore, the court went on, to limit the scope of Title III's prohibition to discrimination in access "to physical structures ... would run afoul of the purposes of the ADA and would severely frustrate Congress's intent."97

93. 136 ConG. REC. S9695 (daily ed. July 13, 1990) (statement of Sen. Dole).

94. 42 U.S.C. § 12101(b).

95. Carparts, 37 F.3d at 19 (quoting H.R. REP. No. 101-485 (II), at 99 (1990), reprinted in 1990 U.S.C.C.A.N. 303, 382); see also Kotev v. First Colony Life Ins. Co., 927 F. Supp. 1316, 1321 (C.D. Cal. 1996).

96. Carparts, 37 F.3d at 19.

97. Id. at 20. One anthor, Luke Sobota, cites additional legislative history to support the opposite conclusion. "[T] he Senate Committee on Labor and Human Resources," he notes, "expressed the "need to define places of public accommodation[s] to include all places open to the public, not simply restaurants, hotels and places of entertainment... because discrimination against people with disabilities is not limited to specific categories of pubhic accommodation s." Sobota, supra note 17, at 262. 


\section{The Parker Opinion}

The en banc opinion of the Sixth Circuit in Parker v. Metropolitan Life Insurance $\mathrm{Co}^{98}$ contains the most extensive defense to date of the physical-access interpretation of Title III. A critique of that interpretation therefore requires discussion of the Parker court's opinion. As the following discussion argues, the Parker court's view reflects a limited picture of disability discrimination, a picture of simple, concrete impediments to the ability of people with certain easily identified disabilities to get around in the world. In this erroneous picture, prohibiting forms of discrimination that are more subtle, coinplex, or abstract, such as discrimination in the terms of msurance pohcies, is contrary to common sense.

Clinical depression had forced plaintiff Ouida Sue Parker to leave her job. ${ }^{99}$ Her employer, Schering-Plough Health Care Products, provided health insurance to its einployees through Metropolitan Life, and Parker received disability benefits through this plan. ${ }^{100}$ The plan had a typical differential in disability benefits for physical and mental disabilities, providing benefits until age sixty-five for physically disabled beneficiaries, but for only twenty-four months for inentally disabled beneficiaries. ${ }^{101}$ After reaching the twenty-four-month cutoff, Parker sued the employer under Title I and the insurer under Title III, claiming that the differential constituted disability discrimination. ${ }^{102}$

The district court granted the defendants' summary judgment motion on all clains. ${ }^{103}$ That court's analysis reveals an interesting dynamic between Title I and Title $\mathrm{II}$ as applied to insurance. The threshold question for all Title I claims is whether the plaintiff is a "qualified individual with a disability." 104 This requirement presents, or may appear to present, every employee plaintiff who suffers discrimination with respect to disability insurance with a catch-22: While still able to work, the plaintiff did not have a disability. After being forced out of work by the onset of the disability, the plaintiff is no longer a qualified individual. ${ }^{105}$ Therefore the plaintiff was never both a qualified individual and an individual with a disability at the same time, and cannot satisfy the initial requirenents. While able to work, the plaintiff loses on the disability prong: Once unable to work, he loses on the qualified-individual prong. Discrimination in

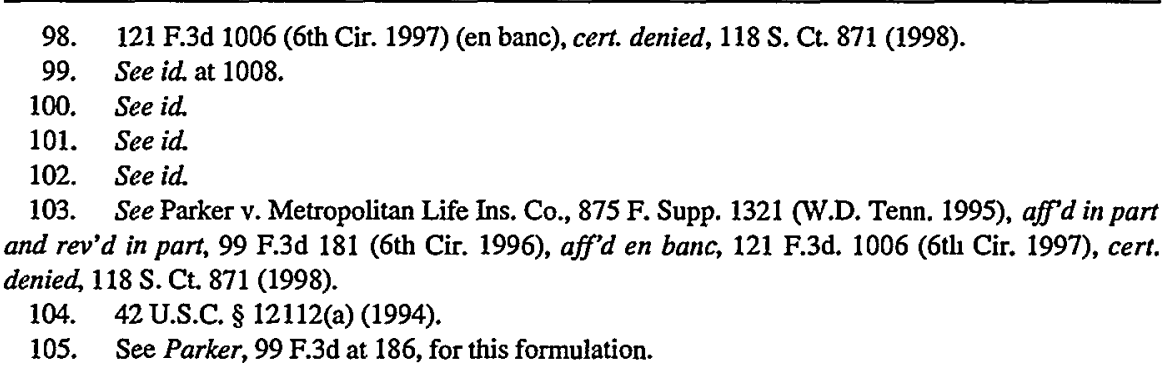


disability insurance benefits is thus not actionable at any stage under Title I. So, at any rate, the district court held. ${ }^{106}$

Title III, however, does not contain the concept of a "qualified individual," 107 and so this particular catch-22 does not exist for Title III plaintiffs. Thus, Parker's lawyers were clever to include a Title III claim in her complaint. Even if the "qualified individual" catch-22 would defeat her Title I claim against her employer, the Title III claim against the insurer as a public accommodation would reinain. If successful, this strategy would patch the hole in Title I that the concept "qualified individual with a disability" creates for totally disabled former employees subject to discrimination in benefits.

This strategy did not work in the district court, however, which held first that Parker was not a qualified individual under Title I, then dismissed her Title III claim with the typical defendant's theory that section 302(a) covers only physical access to facilities. ${ }^{108}$ The strategy was more successful, however, on appeal. A three-judge panel affirmed the district court on Parker's Title I claim, expressing soine regret about the catch-22 but ultiInately holding that Title $\mathrm{T}$ s language forced its hand; ${ }^{109}$ but it reversed on the Title III claim, ${ }^{110}$ adopting Parker's interpretation of section 302(a). ${ }^{111}$

On en banc rehearing, Parker's fortunes changed. The court did not reexamine the Title I issue. ${ }^{112}$ Dealing only with Title $\mathrm{II}$, the court reversed the panel and affirmed the district court. ${ }^{113}$ In reaching this result the court showed a relatively high degree of sensitivity to the weaknesses of the physical-access theory. It is worth noting, first, that the court was not satisfied to let the outcoine in the case rest on the physical-access theory alone, even though it did not address section 501(c), the insurance safe-harbor provision. The court also relied on two other, narrower grounds. First, the court held that the case did not fall under Title III because Title I occupies the field of employee benefits: "[D]iscrimination in the provision of fringe benefits during employnent is governed strictly by Title I and the provision of a long-term disability plan is a fringe benefit of einploynent." 114 This position is unpersuasive, as none of the statutory language or regulations the court cites support the proposition that Title I

106. See Parker, 875 F. Supp. at 1325-26.

107. Compare the "General Rule" of Title I, 42 U.S.C. $\$ 12112(a)$, which provides that "[n]o covcred entity shall discriminate against a qualified individual with a disability because of the disability," with the "General Rule" of Title III, id. $\$ 12182($ a), which provides that "[n]o individual shall be discriminated against on the basis of disability ...."

108. See Parker, 875 F. Supp. at 1328-29.

109. See Parker, 99 F.3d at 185-87.

110. See id. at 194.

111. See id. at 187-90.

112. See Parker, 121 F.3d at 1009 \& n.2.

113. See id. at 1009.

114. Id. at 1015. 
covers employee benefits to the exclusion of other parts of the ADA. ${ }^{115}$ There is, therefore, nothing to refute the proposition that Titles I and III could overlap on this point. In particular, the court adduced nothing to show that even if Congress intended Title I to be the exclusive cause of action against employers, Title III could not support a separate cause of action against the insurer in the same case.

The second, narrower alternative theory presented by the court was that arbitrary discrimination against a person with a disability is perfectly acceptable under the ADA, provided that this discrimination is in favor of persons with different disabilities rather than persons without disabilities. "[T] he ADA does not mandate equality between individuals with different disabilities ... . [but only] prohibits discrimination between the disabled and the nondisabled." 116 The authority for this view, although not a matter of anything in the statutory language itself, is not insubstantial; ${ }^{117}$ but an examination of it is outside the scope of this Comment.

The court's use of these two theories demonstrates that it was unsure of its ground when it advanced the physical-access theory. That this is a symptom of a larger infirmity is apparent from the court's lack of coherence in trying to explain the physical-access theory. The court's central proposition in its physical-access argument is that while buying an insurance policy directly from an imsurance company may involve access to the goods or services of a physical place, obtaining insurance coverage through an employer does not:

While we agree that an imsurance office is a public accommodation as expressly set forth in $\S 12181(7)$, plaimtiff did not seek the goods and services of an insurance office. Rather, Parker accessed a benefit plan provided by her private einployer and issued by MetLife. A benefit plan offered by an employer is not a good offered by a place of public accommodation. ${ }^{118}$

The court's assertion that "plaintiff did not seek the goods and services of an insurance office" is literally false. MetLife maintains many insurance offices, conceded to be public accommodations, one of which issued Schering-Plough's group policy. The court does not deny that an insurance policy is a good or service. And it is difficult to state that Parker did not

115. See id. at 1014-15. The court cites Title I's provision that employers may not discriminate, see 42 U.S.C. $\S 12112$ (a) (1994), and regulations specifying that employers may not discriminate in providing fringe benefits, see 29 C.F.R. $\$ 1630.4(f)$ (1996). To point out that Title I covers employment benefits, however, does not show that other parts of the ADA do not cover them as well. The court does cite oue case supporting its propositiou, however: "The legislative intent is so clear from the language of Titles I and III that one need not go beyond that language to conclude that employment discrimination is the exclusive province of Title I." Motzkin v. Trustees of Boston Univ., 938 F. Supp. 983, 996 (D. Mass. 1996).

116. Parker, 121 F.3d at 1015.

117. See id. at 1015-19.

118. Id. at 1010 . 
seek "the opportunity to participate in or benefit from"119 the policy. Therefore Parker did seek the goods and services of an insurance office: the goods and services were "of" an insurance office, and Parker sought them. The fact that she did so through her employer does not affect the truth of this proposition one way or the other. ${ }^{120}$ When it says "seeks the goods and services of an insurance office," the court seeins to mean "physically go to an insurance office seeking goods and services," but to put it that way would beg the question of whether physically going to the office matters. The court's formulation speaks only of seeking the services of the office, and it is possible to seek the services of an office without going there. Seeking the services of the office by phone is one way of doing this, and seeking them through the intermediary of an employer is another.

The court enploys a variety of arguments to skirt the problem of the literal falsehood of its major premise. First, the court asserts that "the good that plaintiff seeks is not offered by a place of public accommodation. The public cannot enter the office of MetLife or Schering-Plough and obtain the long-term disability policy that plaintiff obtained."121 The implication follows that nothing that is not physically entered by the general public can be a public accommodation, thus nothing that is not obtained from a building normally entered by the general public can be a good or service of a public accommodation. But that proposition conflicts with the Title III provision on which the Parker court inost heavily relies: ${ }^{122}$ the list of fiftysix entities defined as public accommodations. ${ }^{123}$ The subsection containing this list provides that the listed.entities simply "are considered public accommodations for the purposes of this subchapter, if the operations of such entities affect commerce." 124 That is, insurance offices and everything else listed are deemed public accommodations regardless of how "public" they may be. The statute says nothing about the general public being able to enter.

119. 42 U.S.C. \& $12182(\mathrm{~b})(1)(\mathrm{A})(\mathrm{ii})$.

120. The Sobota Comment supports the physical access interpretation in the following way: The problein with the Carparts analysis [arguing that the physical access interpretation is wrong] is demonstrated by substituting Carparts's nonphysical definition of public accommodation in the text of the general antidiscrimination provision. After substitution, the provision would read: "No individual shall be discriminated against in the full and equal enjoyment of... any place of nonphysical entities." The provision is rendered nonsensical....

Sobota, supra note 17 , at 263 . Sobota makes the same mistake as the Parker court. No substitution is necessary because it is literally false that a Title III insurance plaintiff does not gain access to a service of a physical place. Section 302(a) covers such a case exactly as written: It forbids discrimination in the enjoyment of a service of a place.

121. Parker, 121 F.3d at $101 \mathrm{I}$.

122. See id. at 1010.

123. See 42 U.S.C. § 12181(7).

124. Id. (einphasis added). 
The court's next argument immediately follows: 'Parker did not access her policy from MetLife's insurance office. Rather, she obtained her benefits through her employer. There is, thus, no nexus between the disparity in benefits and the services which MetLife offers to the public from its insurance office." 125 This argument is unpersuasive. The court admitted in a footnote that the first of these three sentences is irrelevant, saying that it does not matter that Parker "physically did not access her policy from MetLife's insurance office." ond sentence, that she obtained the goods or services of MetLife's insurance office through her employer does not alter the literal truth, as argued above, that she obtained the goods and services of an insurance office. The "nexus" the court requires is thus its own invention. Evidently the court means by "nexus" a connection, not mediated by an employer or otherwise, between the plaintiff and the public accommodation. But the statute suggests no such requirement, and the court does not even attempt to show that it does.

In a third line of argument, the court seeks to bolster its claim that Parker did not seek the services of a physical place (that is, an insurance office), by arguing at length that a public accommodation is by definition a physical place. ${ }^{127}$ The court first observes that every example of a public accommodation listed in section $301(7)$ is a physical place. ${ }^{128}$ Then it applies "the statutory canon of construction, noscitur a sociis," meaning a thing "is known from its associates." ${ }^{29}$ Because everything in the list of public accommodations is a physical place, the court argues, we apply this canon and reach the conclusion that a public accommodation is a physical place..$^{130}$ In reaching this conclusion, the court expressly rejects the First Circuit's argument in Carparts that "Congress clearly contemplated that 'service establishments' include providers of services which do not require a person to physically enter an actnal physical structure."131 But to conclude that Congress did not contemplate this result from the premise that a public accommodation is a physical place is a non sequitur. Carparts says that a plaintiff does not have to enter a physical place to have availed herself of the goods and services of a public accommodation; it does not argue that a public accommodation need not be a physical place. Discrimination

125. Parker, 121 F.3d at 1011 (citing Pappas v. Bethesda Hosp. Ass'n, 861 F. Supp. 616, 620 (S.D. Ohio 1994), which also called for such a "nexus" between the discrimination and fcaturcs of the insurance office).

126. Parker, 121 F.3d at 1011 n.3.

127. See id. at 1014.

128. See id.

129. Id. (quoting BLACR's LAW DictionaRY 1060 (6th ed. 1990)).

130. See Parker, 121 F.3d at 1014.

131. Id. at 1013 (quoting Carparts Distrib. Ctr., Inc. v. Automotive Wholesaler's Ass'n, 37 F.3d 12, 19 (1st Cir. 1994)). 
in the provision of services by a public accommodation need not be linked with the discriminatee actually going to the place.

A key ambiguity in the insurers' position throughout the Title III insurance cases is apparent here. Saying that, in order to state a claim, a plaintiff must have been discriminated against with respect to physical ability to make use of the goods or services of a public accommodation is different from saying that the public accommodation must be a physical place. The former requirement is much inore difficult for a plaintiff to meet, because it excludes discrimination in access to goods and services by phone or inail or through an employment relationship. The latter, however, is practically always satisfied. Indeed, it is difficult to imagine a good or service that is not provided by an entity that somewhere has a physical facility. In mistaking the latter requirement for the former, courts create a hurdle for plaintiffs which the statute itself does not require.

The Parker court further buttresses its rejection of the Title III claim by invoking two analogies to situations in which a plaintiff seeks the goods or services of a physical place but, according to the court, would not be covered by Title III. Both analogies have force and deserve considered answers froin the plaintiffs' side, for if the analogies are apt, the physicalaccess theory is unnecessary to defeat Title III insurance plaintiffs.

The first analogy is between an insurance coinpany providing a group imsurance plan through an employer on the one hand and a wholesale coinpany on the other. ${ }^{132}$ The court cites the view of the Department of Justice that wholesale coinpanies are covered by Title III only to the extent that they have operations serving end users directly; their operations selling only to other businesses are not covered, according to the regulations cited. ${ }^{133}$ "Thus," the court concludes without further arguinent, "the offering of disability policies on a discounted rate solely to a business is not a service or good offered by a place of public accommodation."'134

It should be noted, first, that the policy of excluding wholesale companies from Title III with respect to their operations serving other businesses is a regulatory creation. The language of the statute does not suggest such a reading. On the contrary, Title III specifies "other sales or rental establishment" in the list of public accommodations, with no distinction between wholesale and retail sales. ${ }^{135}$ And certainly no one will suggest that a wholesale company is not a physical place. It appears that the Department of Justice and the Parker court presuppose a limited definition of the term "public," according to which one leaves one's role as a inember of the public when assuming the role of a customer of a wholesale

132. See Parker, 121 F.3d at 1011-12.

133. See id. (quoting 28 C.F.R. pt. 36, app. B at 604 (1996)).

134. Parker, 121 F.3d at 1012.

135. 42 U.S.C. $\S 12181(7)(E)$ (1994). 
company or an employee. This notion is consistent with the court's assertion, noted above, that it is crucial that the public cannot enter the insurer's offices. ${ }^{136}$

Despite the lack of a statutory basis for limiting the meaning of "public" in this way, the Department of Justice's position does have some intuitive plausibility, and so the analogy between wholesale companies and providers of group health insurance to employers deserves to be explored. A provider of insurance plans to employers is not literally a wholesale company because the distinction between selling at wholesale and selling at retail makes sense only for goods, ${ }^{137}$ not for services, and because employers do not retail imsurance (that is, sell it at a marked-up price). It is therefore necessary to examine the policies behind the supposed noncoverage of wholesale companies before it can be determined whether the same policies should apply to those who provide insurance to employers. The analogy, I argue, is false, even if the Department of Justice's theory regarding wholesale companies is correct.

The policy behind the supposed noncoverage of wholesale companies is obscure. The cited regulations offer no explanation. One possible explanation may be as follows: A wholesaler's discrimination might be thought to affect only the retailer, not the end user. The end user, the consumer, is the intended beneficiary of Title III, according to the theory that Title III protects only the "public" and that retailers buying from wholesalers are not inembers of the "public." Even if the wholesaler's facility is inaccessible or the wholesaler refuses to sell to, or demands a higher price from, disabled retailers, the retailer is still capable of getting the product out to the consumer in a nondiscriminatory way, perhaps purchasing it from another wholesaler. This is possible because of the complete independence of its operation and policies from those of the wholesaler. The retailer is an opaque medium, as it were, between her suppliers and the consumer.

The analogy fails, however, because an employer is better conceived of as a transparent mediuin between the insurer and the employees. The employer does not mediate in the stream of insurance purchases for reasons of its own, the way a retailer of goods mediates in the stream of merchandise purchases. The employer is not, in other words, im the business of selling insurance (as is an independent insurance agent). The employer simply passes the insurance from the insurer to the employees as a convenient conduit, primarily serving the goals of the employees and the insurer rather than its own. Because the employer is not in the business of

136. See Parker, 121 F.3d at 1011.

137. A "wholesale dealer" is defined as "[o]ne who sells goods in gross to retail dealers rather than selling in smaller quantities directly to consumers." A "wholesaler" is "[o]ne who buys large quantities of goods and resells them in smaller qnantities to retailers or other merchants, who in turn sell to the ultimate consumer." BLACK's LAw DictionaRY 1591 (7th ed. 1999). 
selling insurance, the only actor in the transaction that is in that business is the insurer. It would not inake sense to relieve the insurer of the responsibility of providing services without discrimination, because then no profittaking actor in the transaction would have this responsibility.

This difference justifies disparate treatment of the insurer and wholesaler for Title III coverage purposes. The retailer has a duty to make sure the wholesaler's discrimination does not cause discrimination against its consumers, because the retailer is in the business, for himself, of getting the goods to the end user. That is why we hold the retailer, and not the wholesaler, responsible. We hold him responsible by calling his operation, and not the wholesaler's, a public accommodation. The same responsibility does not apply to einployers and insurers because the einployer is not in the business, for itself, of providing insurance to the end user, but lies instead as a passive platform on which the transaction between a group of einployees and the insurer occurs. This is so even when the einployer contributes its own money to the premiums. Indeed, the employer then becomes even inore transparent, merging with the employees as consuiners and disappearing as a middleman. Thus the alleged noncoverage of wholesale coinpanies does not imply the noncoverage of insurers providing group plans through einployers.

The second analogy the Parker court employs compares the contents of books and videotapes to the contents of insurance policies. The court compares an insurer's providing an employer "a long-term disability policy" that contains certain discriminatory coverage himitations to a bookstore's not offering Braille books or a video store's not offering captioned videos. ${ }^{138}$ In none of these three cases is there a Title III violation, the court says. It quotes Department of Justice regulations stating that "[t]he purpose of the ADA's public accommodations requirements is to ensure accessibility to the goods offered by a public accommodation, not to alter the ... mix of goods that the public accommodation has typically provided." 139

Again, the applicability of the Department of Justice's interpretation is open to question. The "contents of insurance policies" differ from goods such as books and videos in that the contents of insurance policies are entirely abstract. They are, im other words, a inatter of the "policies, practices, or procedures"140 or "eligibility criteria"141 or "standards or

138. See Parker, 121 F.3d at 1012-13.

139. Id. at 1012 (quoting 28 C.F.R. pt. 36, app. B at 630 (1996)). The court also cites other Departmeut of Justice regulations providing that Title III does cover "the substantive terms of insurance contracts," but then rejects these as "incousistent with [the Department of Justice's] regulations and the statutory text." Parker, 121 F.3d at 1012 n.5 (citing DOJ Technical Assistance Manual $\S$ III-3.11000, reprinted in Americans with Disabilities Act Manual (BNA) at 90: 0917).

140. 42 U.S.C. \& 12182(b)(2)(A)(ii).

141. Id. $\$ 12182(\mathrm{~b})(2)(\mathrm{A})(\mathrm{i})$. 
criteria or methods of administration"142 that Title III expressly covers. Saying that Title III does not cover insurance policies' contents because coverage would be an interference with the "mix of goods and services" offered by the insurer is like saying that a barber shop is permitted to refuse service to wheelchair users because its "mix of services" does not include haircuts for people using wheelchairs. The court's interpretation of the "mix of goods and services" regulation swallows Title III's provisions on policies, eligibility criteria, and methods of administration.

Chief Judge Posner's opinion for the Seventh Circuit in Doe v. Mutual of Omaha Insurance Co. ${ }^{143}$ relied primarily on this same analogy. In that case, the insurance company had refused to sell the plaintiffs health insurance policies that covered AIDS and AIDS-related conditions on the same terms as other illnesses. In particular, one policy had a lifetime benefits cap for these illnesses of $\$ 25,000$, and the other had a similar cap of $\$ 100,000$; the lifetime cap for all other conditions was $\$ 1$ million. ${ }^{144}$ The effect of these caps was, for instance, that if an insured with HIV contracted pneumonia, benefits for the pneumonia would be capped at $\$ 25,000$ or $\$ 100,000$, while an insured without HIV who contracted pneumonia could receive benefits for pneumoma up to $\$ 1$ million. ${ }^{145}$ In holding for the insurance company, Chief Judge Posner relied on the mixof-goods-and-services rationale, stating that "section 302(a) ... does not regulate the content of the products or services sold in places of public accommodation." ${ }^{146}$ The judge asserted that

[t] he common sense of the statute is that the content of the goods or services offered by a place of public accommodation is not regulated. A camera store may not refuse to sell cameras to a disabled person, but it is not required to stock cameras specially designed for such persons. Had Congress purposed to impose so enormous a burden on the retail sector of the economy and so vast a supervisory responsibility on the federal courts, we think it would have made its intention clearer and would at least have imposed some standards. ${ }^{147}$

This follows the same logic as the Parker court's analogy to Braille books and captioned videos: It compares the notion of requiring insurers to cover the conditions of disabled insureds on the same terms as the conditions of the nondisabled or the conditions of those with different disabilities to the notion of requiring retailers to stock products specially designed for disabled customers. The comparison is unpersuasive. Unlike a book in

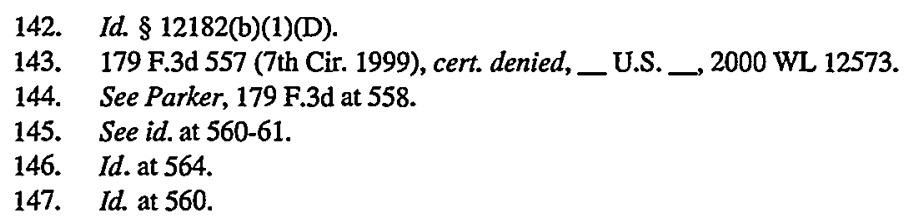


ordinary print, the insurance policies at issue here were deliberately designed to be less useful to people with a specified disability than to everyone else. Judge Evans, dissenting, saw this distinction.

[A]s I see it we are not being asked to regulate [the] content [of insurance policies]; we are being asked to decide whether an insurer can discriminate against people with AIDS, refusing to pay for them the same expenses it would pay if they did not have AIDS. The ADA assigns the courts the task of passing judgment on such conduct....

Chief Judge Posner's opinion likens the insurance company here to a cannera store forced to stock canneras specially designed for disabled persons. While I agree that the ADA would not require a store owner to alter its inventory, I think the analogy misses the mark. The better analogy would be that of a store which lets disabled customers in the door, but then refuses to sell them anything but inferior cameras. To pick up on another analogy raised at oral argument, we are not being asked to force a restaurant to alter its menu to accommodate disabled diners; we are being asked to stop a restaurant that is offering to its nondisabled diners a menu containing a variety of entrees while offering a menu with only limited selections to its disabled patrons. ${ }^{148}$

Just like the Parker court, the Doe court chose to interpret the deliberate infliction of unequal treatment on disabled insurance custoiners as if it were the same as a decision to stock a mix of goods that happens not to include a good that would be valuable to a disabled customer. This choice, again, implies that this proposition, that the ADA does not control the mix of goods and services that public accommodations may offer, can be applied to justify any discrimination through policies, eligibility criteria, and methods of administration by redescribing such policies, criteria, and methods as choices to provide a certain mix of goods and services.

When the court said that Parker "did not seek to access the goods and services of an insurance office," I believe it was motivated by a certain picture of discrimination that explains why the court can think that this false statement is true. The picture is of a wheelchair user attempting to enter a building and being unable to do so. The court employed this picture as the paradigm of disability discrimination under Title III. What the court could analogize to this picture, it terned discrimination on the basis of disability: a blind elevator passenger unable to reach his floor because the buttons are not labeled in Braille; a deaf consumer unable to place an order with a mail-order house because of the lack of a telephone device for the deaf on the other end. That which does not mirror this picture, the court refused to see as violating the ADA: For example, insurance offered on

148. Id. at 565 (Evans, J., dissenting). 
discriminatory terms through an employer. This narrowing approach has something fundamentally im common with the approach the Supreme Court took recently in deciding three cases involving the definition of disability under the $\mathrm{ADA} .^{149}$ The Court chose to accept a narrow interpretation of the ADA's definition of disability primarily because it concluded the broader one offered by plaintiffs would include a counterintuitively large nuniber of people within the ADA's protection. The definition of a person with a disability as one who has an impairment that "substantially limits one or nore of the major life activities," or who has a record of such an impairment or is regarded as having such an impairment, ${ }^{150}$ the Court held, should be interpreted to include only those people who are substantially limited even while employing mitigating measures. ${ }^{151}$ This means, for instance, that even though a person is denied employment because of her vision impairment, she is not protected by the ADA if her vision is corrected by eyeglasses, because she is not substantially limited in the life activity of seeing while wearing the glasses. ${ }^{152}$ The Court chose this interpretation primarily because it produces a smaller number of protected individuals. ${ }^{153}$ Indeed, the Court emphasized that the number of protected persons its interpretation produces is closer to the forty-three million figure mentioned in the ADA itself. ${ }^{154}$ The Court's focus on people who wear glasses, use hearing aids, or have high blood pressure, ${ }^{155}$ however, suggests that it recognized only conditions that conform to a narrow notion of disability that is familiar to the public and accepted as common sense, rather than the broad, new, and encompassing notion that advocates argue the ADA offers. The picture of public accommodation discrimination as the lack of ramps and similar facilities also manifests this impulse to limit the reach of disability antidiscrimination law to the most familiar and unprobleniatic of applications.

The ADA's conception of public accommodation discrimination is not limited in this way, lowever, because the ADA never limits

149. See Sutton v. United Air Lines, 119 S. Ct. 2139 (1999); Murphy v. United Parcel Serv., 119

S. Ct. 2133 (1999).

150. 42 U.S.C. $\$ 12102(2)$ (1994).

151. See, e.g., Sutton, 119 S. Ct. at 2146.

152. See id. at 2149.

153. See id. at 2147-49. The Court stated:

Finally, and critically, findings enacted as part of the ADA require the conclusion that Congress did not intend to bring under the statute's protection all those whose uncorrected conditions amount to disabilities. Congress found that "some $43,000,000$ Americans have one or more physical or mental disabilities, and this number is increasing as the population as a whole is growing older." 12101 (a)(1). This figure is inconsistent with the definition of disability presented by petitioners [which would include a substantially larger number of persons].

Id. at 2147.

154. See 42 U.S.C. § 12101(a)(1).

155. See Sutton, 119 S. Ct. at 2147. 
discrimination to matters involving a "physical ability to make use" of something. The court tried to shore up its position by insisting that public accommodations must not be nonphysical, and by basing its decision on two additional grounds (the employer-intermediary is like a wholesaler; Title III does not affect the "contents" of services). But the insistence that no entity lacking physicality is covered is pointless, and the additional grounds are not persuasive. Thus the court is left with no support for its conclusion.

III

The Meaning of the Safe Harbor Provision, Section 501(c)

The second ADA section this Comment examines forms the basis of the theory that insurers are immunized from liability under the Act. Section 501(c), the ADA's "safe harbor" provision, states that

Subchapters I through III of this chapter and title IV of this Act shall not be construed to prohibit or restrict ... an insurer ... from underwriting risks, classifying risks, or administering such risks that are based on or not inconsistent with State law.... [This provision] shall not be used as a subterfuge to evade the purposes of subchapter I and III of this chapter. ${ }^{156}$

This provision has provoked a debate about what restrictions on the ADA's applicability to insurance its drafters intended. Did the drafters inean to exeinpt insurers altogether, or only to exempt "underwriting risks" if consistent with state law? And what did they mean by creating an exception to the exception for "subterfuge?"

Before these questions can be answered, it is necessary to state some background propositions about insurance. When insureds are divided into classes that are charged different premiums, three rules of law are logically available. First, the classification used to divide the insureds can be unregulated, as it would be deemed legal regardless of its basis. I will call this position "No-Law." Second, the classification can be banned or restricted because it constitutes an undesirable form of discrimination, so that those the insurer wishes to divide must be placed in one class and charged the same premium for the same benefit, even though as separate groups they present different risks. I will call this position "Ban." Third, the classification can be required to be statistically justified-that is, risks shown by statistics to be similar must be grouped together. The classification will be prohibited as unfairly discriminatory only if it treats differently risks that are statistically alike. I will refer to this position as "Risk-Basis." 157

156. 42 U.S.C. § 12201 (c).

157. There is a danger of misreading the legislative history if the difference between Ban and Risk-Basis is not carefully observed. Mr. Sobota seems to make this mistake when he attempts to 
To determine the meaning of section 501(c), we must first determine which of these three positions on insurance discrimination the ADA adopts. In effect, courts holding for insurers adopt the No-Law position when they hold that section 501(c) exempts insurers from liability under Title $\mathrm{III} .{ }^{158}$ Courts holding for plaintiffs, by contrast, adhere to the RiskBasis position. They assert that section 501(c) defines as discrimination only those disability-based insurance decisions that are not supported by actuarial data. ${ }^{159}$ The cases show the wide range of situations this definition covers. In Chabner v. United of Omaha Life Insurance Co., ${ }^{160}$ the defendant imsurance company failed to produce actuarial data to support its decision to charge the thirty-five-year-old plaintiff double the usual premium for life insurance because he had a form of muscular dystrophy that was projected to shorten his life by four years. In Parker, ${ }^{161}$ the insurer imposed a benefits limit of two years for mental disabilities while covering physical disabilities to age sixty-five. In Carparts, ${ }^{162}$ the insurer had a benefits cap of $\$ 25,000$ for AIDS. In Doukas $v$. Metropolitan Life Insurance Co. ${ }^{163}$ the insurer refused disability insurance coverage to a plaintiff with bipolar disorder. Under the Risk-Basis interpretation of section 501(c), each of these disability-based insurance decisions would be unlawful unless the insurer could produce actuarial data justifying both the fact and the degree of the difference in treatment between the disabled and nondisabled insureds. Under No-Law, the insurer's ability to produce actuarial data would be irrelevant, as an actuarial justification for the decision would be unnecessary.

The conflict on this issue springs from statutory ambiguity. The section seems clearly to create an exception for insurance, but states the exception vaguely, and compounds the problem by adding an unclear exception to the exception. Courts holding for plaintiffs support their position by citing legislative history interpreting the subterfuge clause as requiring disability-based decisions to be based on actuarial data. ${ }^{164}$ Courts holding for defendants proceed by attacking that interpretation of the

support the No-Law reading of section 501(c) by quoting a committee report's assertion that without that section, the ADA could be violated by an insurer that "treats disabled persons differently under an insurance or benefit plan because they represent an increased hazard of death or illness." Sobota, stupra note 17, at 266-67 (quoting S. REP. No. 101-116, at 84-86 (1989)). But this language supports the RiskBasis reading of section 501(c) better than the No-Law reading, because it reflects the view that different treatment because of an increased hazard should not be a violation.

158. See, e.g., Leonard F. v. Israel Discount Bank, 967 F. Supp. 802, 804-06 (S.D.N.Y. 1997).

159. See, e.g., Chabner v. United of Omaha Life Ins. Co., 994 F. Supp. 1185, 1193 (N.D. Cal.

1998).

160. See id. at 1187.

161. Parker v. Metropolitan Life Ins. Co., 121 F.3d 1006, 1008 (6th Cir. 1997) (en banc), cert. denied, 118 S. Ct. 871 (1998).

162. Carparts Distrib. Ctr., Inc. v. Automotive Wholesaler's Ass'n, 37 F.3d 12, 20 (1st Cir. 1994).

163. 950 F. Supp. 422, 429 (D.N.H. 1996).

164. See infra notes $166-73$ and accompanying text. 
subterfuge clause, rather than by advancing an independent argument for reading the section as an unlimited exception. ${ }^{165}$ In this Part, I argue that the requirement that disability-based insurance decisions be tied to risk data is the correct interpretation of section 501(c). As I explain in Part III.A, I agree with courts that attack the subterfuge strategy for reaching this result. However, I believe there is a better approach to this issue available to plaintiffs' attorneys, as I explain in Part III.B, below.

\section{A. The Subterfuge Clause as the Basis of Requiring Risk-Based Insurance Decisions: An Unsound Strategy}

Most courts that have held section 501(c) to require risk-based insurance decisions have reached that result through an interpretation of the "subterfuge" clause of section 501(c). These courts have supplied meaning for the subterfuge clause by referring to certain parts of the ADA's legislative history. Explaining that "[s]ection 501(c) may not ... be used as a subterfuge to evade the requirements of this Act," ${ }^{166}$ the House Judiciary Committee specifies that an imsurance plan

inay not refuse to insure or refuse to continue to insure, or limit the anount, extent, or kind of coverage available to an individual, or charge a different rate for the saine coverage solely because of a

165. See, e.g., Ford v. Schering-Plough Corp, 145 F.3d 601, 610-12 (3d Cir. 1998), cert. denied, 119 S. Ct. 850 (1999); Leonard F. v. Israel Discount Bank, 967 F. Supp. 802, 804-06 (S.D.N.Y. 1997). The Leonard F. court also cites legislative history stating that section 501(c) was added "to make it clear that this legislation will not disrupt the current nature... of the insurance iudustry in ... underwriting ... and similar ... activities based on classification of risks as regulated by the States." Leonard F., 967 F. Supp. at 805 (quoting S. REP. No. 101-116, at 84-86 (1989)). But this language does not solve the problem Title III insurance plaintiffs present, uamely whether insurers are allowed to ignore risk classification data when making disability-based insurance decisions.

Both the Ford and the Leonard F. courts also cite the McCarran-Ferguson Act's provision that "[n]o Act of Congress shall be construed to invalidate, impair, or supersede any law enacted by any State for the purpose of regulating the business of insurance ... unless such Act specifically relates to the business of insurance." 15 U.S.C. $§ 1012(b)$ (1994). But neither court explains what law enacted by a state would be invalidated, impaired, or superseded, and so neither shows how the McCarranFerguson Act is relevant.

A small number of subsequent cases, however, has continued to develop the issue of the interaction betweeu the ADA and the McCarran-Ferguson Act. See Doe v. Mutual of Omaha Insurance Co., 179 F.3d 557, 563-64 (7th Cir. 1999) (holding that the McCarran-Ferguson Act precludes the plaintiff's ADA claim); Winslow v. IDS Life Ins. Co., 29 F. Supp. 2d 557, 563-64 (D. Minn. 1998) (bolding that the McCarran-Ferguson Act does not preclude application of the ADA to insurance practices). The most important holding in this area is Doe, 179 F.3d at 563-64, in which the Seventh Circuit held that even if section 302(a)'s prohibition on discrimination in the provision of services by a public accommodation did apply to insurance policies, the McCarran-Ferguson Act would preclude courts from considering whether insurance decisions are actuarially sound. Thus courts would be able to determine only whether an insurer has discriminated by refusing outright to deal with disabled customers, not by refusing to insure or by insuring on less favorable terms despite a lack of actuarial evidence that those customers presented increased risk. Although the case law is still slight, it is clear that this issue could becoine a major one.

166. H.R. ReP. No. 101-485(II), at 71 (1990), reprinted in 1990 U.S.C.C.A.N. 445, 494; see also S. REP. No. 101-116, at 84-86 (1989). 
physical or mental impairment, except where the refusal, limitation, or rate differential is based on sound actuarial principles, or is related to actual or reasonably anticipated experience. ${ }^{167}$

At least two district courts have used this language to support a holding that a disability-based insurance decision not based on sound actuarial principles or related to actual or reasonably anticipated experience can, for that reason, constitute a subterfuge. ${ }^{168}$ The Sixth Circuit panel in Parker ${ }^{169}$ reversed in an en banc rehearing, ${ }^{170}$ reached a similar conclusion. Undertaking to "fashion a legal standard" for evaluating facts under the "subterfuge" clause, the court in Cloutier v. Prudential Life Insurance Co. ruled that "insurers retain their section 501(c) exemption so long as their underwriting decisions are in accord with either (a) sound actuarial principles, or (b) actual or reasonably anticipated experience."171 Thus these courts use the subterfuge clause to adopt a cost-justification standard for insurance nondiscrimination under the ADA-that is, to adopt RiskBasis.

In its Interim Guidance ${ }^{172}$ on the application of Title I to employerprovided insurance, the Equal Employment Opportunity Commission also interprets the "subterfuge" clause of section 501(c) as the link to the requirement of a statistically based cost justification as the ineaning of nondiscrimination. "'Subterfuge," the Guidance provides, "refers to disability-based disparate treatınent that is not justified by the risks or costs associated with the disability." 173 Although the Guidance applies only to

167. H.R. REP. No. 101-485(III). After citing this passage, Sobota points out that all states have state law requiring, in general, that insurers charge like premiums for like risks. He then points to the "not inconsistent with state law" clause of section 501(c), and concludes that Title III must not regulate insurance because it goes no farther than the state law requirement of charging like premiums for like risks. See Sobota, supra note 17.

This conclusion is unjustified. The point Sobota notes-that state law requires risk-based decision making and that section 501(c) refers to state law-instead supports the view that section 501(c) regulates insurance according to the Risk-Basis conception. It does so, in Sobota's own view of the state law clause, through incorporation by referring to state law requirements.

168. See Cloutier v. Prudential Ins. Ca of Am., 964 F. Supp. 299, 304 (N.D. Cal. 1997); Doukas v. Metropolitan Life Ins. Co., 950 F. Supp. 422, 432 (D.N.H. 1996).

169. Parker v. Metropolitan Life Ins. Co., 99 F.3d 181, 191-92 (6th Cir. 1996).

170. See Parker v. Metropolitan Life Ins. Co., 121 F.3d 1006 (6th Cir. 1997) (en banc).

171. Cloutier, 964 F. Supp. at 304.

172. EEOC Interim Guidance on Application of ADA to Health Insurance, supra note 19, at D22.

173. Id. I III.C.2. Although adopting the cost-justification theory of nondiscrimination (RiskBased), the Interim Guidance also contains a narrow definition of a disability-based insurance distinction that could result in defense judgments in many cases in which a plaintiff with a disability is effectively excluded from an insurance plan despite the absence of a cost justification for excluding her. See id. I B. The Guidance permits the exclusion or limitation of whole categories of care (such as "eye care") and whole categories of procedures (such as "blood transfusions or X-rays") on the ground that these are not "disability-based distinctions." On the other hand, it recognizes as disability-based distinctions, subject to the requirement of cost justification, exclusion of particular diseases or groups of diseases (such as "cancers, muscular dystrophies, kidney diseases"). See id. There is great potential under this rule for restrictions falling especially hard on people with disabilities, but having nothing to 
"assist Commission investigators in analyzing ADA charges"174 against einployers under Title $I^{175}$ and therefore has no application in Title III suits against insurers, the fact that an expert agency chose a certain interpretation is nevertheless persuasive authority in support of the interpretation.

Plaintiffs' lawyers would be unwise to stake the future of Title III's application to insurance on this reasoning. As explained below, there is a long and confused story behind the meaning of "subterfuge" in the ADA, and this confusion makes the "subterfuge" clause an unsatisfactory basis for the rights of Title III insurance plaintiffs. The dictionary meaning of the word is "deception by artifice or stratagein in order to conceal, escape, or evade." ${ }^{176}$ In two cases decided before the ADA was passed, the Supreine Court adopted essentially this definition of "subterfuge," as the word at that time appeared in a similar clause in the Age Discriunination in Employment Act (ADEA). ${ }^{177}$ In United Air Lines v. $M c M a n n^{178}$ and again in Public Employees Retirement System v. Betts, ${ }^{179}$ the Court held that im the context of the ADEA, "subterfuge" ineans "a scheme, plan, stratagem, or artifice of evasion." 180

Congress reacted against this interpretation of "subterfuge" in Betts by passing the Older Workers Benefits Protection Act (OWBPA) ${ }^{181}$ to amend the ADEA. The amendments included the deletion of the "subterfuge" clause and its replacement with a provision prohibiting agebased benefits discrimination unless cost justified. ${ }^{182}$ Relatedly, the ADA's legislative history contains remarks explicitly rejecting the Betts definition. Several legislators imdicated that "subterfuge" does not inean "that there must be some malicious or purposeful imtent to evade the ADA on the part of the msurance company." 183 Some legislators also mentioned the bill that

do with risk or cost. The rule also seems incoherent: How can one justify a difference in policy between singling ont care of eye diseases and singling out care of kidney diseases?

For more detailed criticism of the definition of a disability-based distinction in the Guidance, see H. Miriam Farber, Subterfuge: Do Coverage Limitations and Exclusions in Employer-Provided Health Care Plans Violate the Americans with Disabilities Act?, 69 N.Y.U. L. REv. 850, 905-06 (1994).

174. See EEOC Interim Guidance on Application of ADA to Health Insurance, supra note 19, $\mathbb{\text { II }}$.

175. See id. III (citing Title I's antidiscrimination provisions only).

176. WeBster's NINTH New COLlegiate Dictionary 1177 (1984).

177. Age Discrimination in Einployment Act of 1967, 81 Stat. $603 \S 4(f)(2)$ (providing that the antidiscrimination provisions of the ADEA do not apply to "bona fide employee benefit plan[s] .. . which [are] not a subterfuge to evade the purposes" of the ADEA).

178. 434 U.S. 192 (1977).

179. 492 U.S. 158 (1989).

180. McMann, 434 U.S. at 203; see also Betts, 492 U.S. at 171 (quoting this language from McMann).

181. Pub. L. No. 101-433, 104 Stat. 978 (1990). For the proposition that the OWBPA was a reaction against Betts, see Farber, supra note 173, at 894-95.

182. See Pub L. No. 101-433, § 103(1).

183. 136 CoNG. REC. $S 9697$ (daily ed. July 13, 1990) (statement of Sen. Kennedy); 136 Cong. REC. H4623 (daily ed. July 12, 1990) (statement of Rep. Owens) (same language); 136 CoNG. REC. H4624 (daily ed. July 12, 1990) (statement of Rep, Edwards) (same language). 
was to become the OWBPA, which they had voted for in committee, as making clear their intent to reject the Betts defintion. ${ }^{184}$ Senator Kennedy, for example, stated that "[i]t is important to note that the term 'subterfuge,' as used in the ADA, should not be interpreted in the manner in which the Supreme Court interpreted the term in Public Employee Retirement System of Ohio v. Betts, 109 S. Ct. 256 (1989). . . Indeed, our committee recently reported out a bill to overturn the Betts decision."'185

The complexity of this history has encouraged some courts to reject the use of the legislative history to connect the "subterfuge" clause with the Risk-Basis position. In Leonard F. v. Israel Discount Bank, ${ }^{186}$ the court simply ignored this legislative history, citing Betts for the proposition that "subterfuge" follows its dictionary definition. Moreover, two circuit courts in non-Title III cases have applied the Betts definition of "subterfuge" to other sections of the ADA. In Modderno v. King, ${ }^{187}$ the D.C. Circuit adopted the Betts definition in interpreting the Rehabilitation Act Amendments of 1992, which incorporated several ADA provisions, including section 501(c), ${ }^{188}$ into the Rehabilitation Act of 1973. The court noted that Congress passed the ADA after the Betts decision, and had shown its awareness of the Supreme Court's interpretation of "subterfuge" in Betts by deleting that word from the then-pending Older Workers Benefits Protection Act. Nevertheless, it had retained that word in the ADA. Therefore, the court presumed, Congress must have intended to endorse the Betts definition of subterfuge. ${ }^{189}$ The court also rejected the EEOC Interim Guidance provision on subterfuge for the same reason. ${ }^{190}$ The Eighth Circuit endorsed this reasoning in Krauel v. Iowa Methodist Medical Center ${ }^{191}$ and went on to reject the authority of the ADA sponsors' remarks on Betts in the legislative history as conflicting with the plain meaning of the statute. ${ }^{192}$

It is thus apparent that the question of the meaning of "subterfuge" in the light of various authorities can be argued either way with some persuasiveness. Those courts that ignore the tangled legislative history of the term "subterfuge" and choose the dictionary meaning of the word have the power of inertia on their side. Courts are free to ignore legislative history, and they are especially likely to do so when it is offered in support of a

184. See 136 CoNG. Rec. S9697 (daily ed. July 13, 1990) (statement of Sen. Kennedy); 136 CoNG. REC. H4623 (daily ed. July 12, 1990) (statement of Rep. Owens) (same language); 136 CoNG. REC. H4624 (daily ed. July 12, 1990) (statement of Rep. Edwards) (same language).

185. 136 CONG. REC. S9697 (daily ed. July 13, 1990).

186. 967 F. Supp. 802,806 (S.D.N.Y. 1997).

187. 82 F.3d 1059, 1064 (D.C. Cir. 1996).

188. See 29 U.S.C. $§$ 794(d) (1994).

189. See Modderno, 82 F.3d at 1064-65.

190. See id.

191. 95 F.3d 674, 678 (8th Cir. 1996).

192. See id. at 679 . 
strained interpretation of a statute's language. However lacking the "plain meaning" theory of interpretation may be philosophically, it is nevertheless dangerous not to have the dictionary on your side; and the dictionary clearly favors "stratagem of evasion" over "lack of actuarial data" as the meaning of "subterfuge." Furthermore, although the courts in Modderno and Krauel both held against the plaintiffs, some courts deciding employee benefits cases in favor of plaintiffs also reject the connection advanced by the EEOC between "subterfuge" and cost justification as the standard for nondiscrimination in insurance. One such court explicitly rejected the formulation in the Interim Guidance, ${ }^{193}$ while two more directly linked the underwriting-and-classifying-risks language of section 501(c) to the requirement of actuarial data, without referring to the "subterfuge" clause. ${ }^{194}$ A court wishing to rule against a plaintiff advancing a costjustification theory of discrimination via the "subterfuge" clause is therefore able to draw on cases goimg both ways to justify its outcome.

\section{B. The Concept of Underwriting and Classifying Risks as the Basis of Requiring Risk-Based Insurance Decisions: A Better Solution}

Those who would arrive at Risk-Basis through the subterfuge clause overlook the central logic of section 501(c). That section provides that nothing in the ADA prohibits or restricts insurers "from underwriting risks, classifying risks, or administering such risks" as are consistent with state law. ${ }^{195}$ This exemption, first of all, covers only "underwriting," "classifying," and "administering ... risks." Insurance practices that are not categorized as such are covered by Title III in the same way as other services. As explained below, risk classifying and underwriting are tied to the use of actuarial data; practices not supported by actuarial data are therefore not within the safe harbor of section 501(c).

Courts that resort to the subterfuge clause as a peg on which to hang the Risk-Basis rule do so because they are convinced that there is no other way to get there. These courts read the permission to "underwrit[e] ... classify[ ] . . or administer[ ] . . risks that are ... not inconsistent with State law"196 as meaning that unless the insurance decision in question violates state law, it does not violate the ADA. This reading gives no restrictive force to the fact that it is only decisions that can be characterized as underwriting, classifying, or administering risks that are exenipted from the nondiscrimination provisions of the ADA's substantive titles. As a consequence, these courts hold that only by violating state law

193. See Piquard v. City of East Peoria, 887 F. Supp. 1106, 1124-25 (C.D. Ill. 1995).

194. See Anderson v. Gus Mayer Boston Store, 924 F. Supp. 763, 780 (E.D. Tex. 1996); Schroeder v. Connecticut General Life Ins. Co., Civ. No. 93-M-2433, 1994 WL 909636, at*3-*4 (D. Colo. Apr. 23, 1994).

195. 42 U.S.C. $§ 12201$ (c)(1) (1994).

196. Id. 
or engaging in subterfuge does an insurer violate Title III. The Cloutier court, for instance, asserts that "[t]he plain text of section 501(c) leaves insurance coinpanies vulnerable in two ways," 197 which it identifies as actions inconsistent with state law and subterfuge. ${ }^{198}$ This means that an independent violation of the ADA, not requiring a state law violation as a predicate, requires a determination that an insurance decision was a subterfuge. It follows froin this approach that either (a) disability-based insurance decisions constitute an independent (that is, not state law-based) ADA violation only in those few cases in which the insurer has perpetrated some kind of trick, deliberately to break the law, or (b) the definition of "subterfuge" is not what you would find in Webster's. Courts adopting this approach and holding for plaintiffs therefore go out of their way to define "subterfuge" in an anomalous fashion.

Commentators on section 501(c) have generally agreed with the approach of these courts in not treating the concepts of underwriting and classifying risks as a source of restrictions on insurers. Rather, they have assumed that because section 501(c) says that underwriting and classifying risks will not be prohibited, only the concept of subterfuge remains as a source of restrictions (apart from state law). ${ }^{199}$ These commentators, like the courts, have not affirmatively argued that the concepts of underwriting and classifying are not sources of restriction; rather, they have simply presupposed this.

A safer route to the principle that disability-based insurance distinctions must be cost-justified is available, at least implicitly, in a second strand of opinions favoring plaintiffs. These cases link the requirement of sound actuarial data or actual or reasonably anticipated experience directly to the underwriting-and-classifying language, rather than joining them through the subterfuge clause. ${ }^{200}$ The link is justified by well-established

197. Cloutier v. Prudential Ins. Co. of Am., 964 F. Supp. 299, 303 (N.D. Cal. 1997).

198. See id.

199. See Kimberly A. Ackourey, Insuring Americans with Disabilities: How Far Can Congress Go to Protect Traditional Practices?, 40 EMORY L.J. 1183, 1189-99 (1991) (analyzing the section 501(c) coverage issue exclusively in terms of subterfuge); Farber, supra note 173, at 867,877 (addressing the meaning of "classifying risks" and "underwriting risks" but concluding that these concepts ultimately provide no guidance in determining what insurance practices the ADA prohibits, and that interpretation of the subterfuge clause "will inevitably determine the outcome of most ADA challenges" to insurance decisions); Monica E. McFadden, Insurance Benefits under the ADA: Discrimination or Business as Usual?, 28 ToRT \& INs. L.J. 480, 489 (1993) (treating the underwriting-and-classifyimg-risks language as freeing insurers from liability and only the subterfuge language as restricting them); Ted Storer, The Americans with Disabilities Act: Will the Insurance Field Change?, 20 OHIO N.U. L. REv. 1031, 1035-40 (1994) (discussing only subterfuge as a basis for an insurance violation of the ADA, after concluding that the underwriting-and-classifying-risks language ineans that, apart from subterfuge, the ADA does not affect the insurance industry at all); Bonnie Poitras Tucker, Insurance and the ADA, 46 DEPAUL L. REv. 915, 921 (1997) ("The subterfuge language is the key to analyzing whether an imsurance plan violates the ADA.").

200. Department of Justice regulations "interpreting" section 501(c) merely restate the section verbatim. See 28 C.F.R. $\$ 36.212$ (1995). Commentary provided in an appendix, however, shares the 
usage of the words "underwriting" and "classifying," definitions prominent in an academic and political debate about insurance discrimination that occurred several years ago, before the ADA was enacted. ${ }^{201}$

At least two district courts appear to have used this method to reach the result that Title III insurance discrimination ineans lack of a cost justification. ${ }^{202}$ These courts have a cominon understanding of the provision of section 501(c) that Titles I through IV "shall not be construed to prohibit" insurers from underwriting or classifying risks consistent with state law: that an insurance decision consistent with state law might nevertheless fail to be a case of underwriting or classifying risks, and therefore might still be prohibited, even though it is not a subterfuge.

One district court interpreting section 501(c) in a Title I insurance case makes this point by saying that the subterfuge clause would be redundant if it means that insurance decisions inust be cost justified, because the underwriting-and-classifying language in section 501(c)(1) and (2) already requires cost justification. The court stated that the interpretation of the subterfuge clause as requiring cost justification

seems to be repetitive of the requirements of at least paragraphs (1) and (2) of Section 501(c), which require that benefit plan decisions based on disabilities be based on the grouping of similar risks and sound actuarial principles or active or reasonably anticipated experience to be exempt under the $\mathrm{ADA}$. If a benefit plan or practice qualifies under paragraphs (1) or (2) because it underwrites, classifies, or administers risks based on or not inconsistent with State law and thus is not prohibited by the ADA, what would it inean to interpret Section 501(c)'s subterfuge sentence as providing that if that same benefit plan or practice's disability-based treatment is not justified by the risks or costs associated with the disability, it violates the ADA? It seens that if the benefit plan disability-based distinction or treatunent is not based on the risk or costs associated with the disability, then it would not qualify for 501(c)(1) or (2)'s exception and is prohibited by [the antidiscrimination provision of Title I]. ${ }^{203}$

This interpretation of the underwriting-and-classifying language is supported by the conventional understanding of the function of insurance classification systems. One author, in explaining such systeins, says that "[i]n constructing risk classes, the insurer's goal is to calculate the

approach of this second strand of cases, in that it links the concept of cost justification with that of underwriting and classifying risks directly, without reference to the concept of subterfuge. See 28 C.F.R. pt. 36, app. B at 612-13 (1995).

201. See infra notes 204-07 and accompanying text.

202. See World Ins. Co. v. Branch, 966 F. Supp. 1203, 1208 (N.D. Ga. 1997); Baker v. Hartford Life Ins. Co., No. 94 C 4416, 1995 WL 573430, at *4 (N.D. Ill. Sept. 28, 1995).

203. Piquard v. City of East Peoria, 887 F. Supp. 1106, 1124-25 (C.D. Ill. 1995). 
expected loss of each insured, and to place insureds with similar expected losses into the same class, so that each may be charged the same rate."204

This conventional understanding of insurance classification was the background of a nationwide debate that occurred in the 1970s and 1980s over the question whether sex, age, medical condition, and certain racesurrogate classifications (such as ZIP code) in life, health, property, and auto insurance were unfairly discriminatory. ${ }^{205}$ The debate came to be known as "the insurance classification controversy." ${ }^{206}$ One major position held that risk-based classification is fair regardless of what genuinely riskrelated factors are used, while the opposing side held that the use of the challenged factors should be prohibited even if they are genuinely risk related. ${ }^{207}$ Thus the positions I have called Ban and Risk-Basis dominated the debate. Risk-Basis represented the status quo, while Ban represented a civil rights-oriented reform movement. ${ }^{208}$ No-Law, now advanced by insurers in the Title III context, was not advocated in the debate.

The vitality of the Ban position during the insurance classification controversy is seen in the result the Supreme Court reached in Arizona Governing Committee v. Norris. ${ }^{209}$ The case concerned a retirement plan that charged women employees the same monthly contribution as men during employment but paid lower monthly benefits in retirement. ${ }^{210}$ The difference was predicated on women's greater statistical longevity, and thus was cost justified by actuarial data. ${ }^{211}$ The Court held that the lower benefit rate nevertheless constituted sex discrimination under Title VII of the Civil Rights Act of $1964 .{ }^{212}$ The Court declared that " [e]ven a true generalization about [a] class' cannot justify class-based treatment."213

When the ADA was drafted in the 1980s, the debate between Ban and Risk-Basis thus formed the background for Congress's deliberations. Bills to ban certain classifications as unfairly discriminatory were repeatedly

204. Kenneth S. Abraham, Efficiency and Fairness in Insurance Risk Classification, 71 VA. L. REv. 403, 408 (1985); see also, e.g., Storer, supra note 199, at 1033-34 (explaining that "[i]n creating a policy, insurers group individuals to determine whether coverage should be issued and what premium rates to charge. The risk of eacl group is calculated on the probability of occurrence; higher risks are charged higher premiums, while lower rates are charged to those with lower risks." (footnote omitted)). But cf. Leah Wortham, The Economics of Insurance Classification: The Sound of One Invisible Hand Clapping, 47 Oнго ST. L.J. 835, 845-47 (explaining that insnrers also use a number of factors unrelated to risk in grouping insureds who are to be charged like premiums).

205. See Wortham, supra note 204, at 836.

206. E.g., Regina Austin, The Insurance Classification Controversy, 131 U. PA. L. REv. 517

(1983).

207. See Wortham, supra note 15 , at $360-61$.

208. See id. at 360 .

209. 463 U.S. 1073 (1983).

210. See id at 1074 .

211. See id. at 1077.

212. See id. at 1074 .

213. Id. at 1084 (quoting City of Los Angeles Dep't of Water \& Power v. Manhart, 435 U.S. 702, 709 (1978)). 
introduced in Congress, ${ }^{214}$ and hearings on those bills conducted, ${ }^{215}$ throughout the 1980s. In declining to prohibit or restrict the underwriting or classifying of risks through adoption of section 501(c), Congress apparently chose for the disability context the status quo position that insurance companies had long favored as the desired outcome of the insurance classification controversy, namely that insurance decisions based on actuarial data should not be prohibited as discriminatory.

This conclusion means that the ADA does not adopt for people with disabilities a ban on disability-based insurance decisions, as some reformers wanted during the insurance classification controversy. ${ }^{216}$ Instead, it adopts the status quo position backed by supporters of Risk-Basis. But it also means that the ADA does not adopt the more extreme position insurers now argue for in Title III insurance litigation, that section 501(c) permits thein to nake disability-based insurance distinctions to the detriment of disabled insureds despite the lack of a statistical justification, No-Law. The context of the insurance classification controversy shows that section 501(c)'s underwriting-and-classifying language means only that insurers are not prohibited from grouping people with disabilities with others presenting similar risks and charging preeniums accordingly. Thus the "safe harbor" created by section 501(c) protects only the traditional practice of charging like prenniums for like risks, and the general antidiscrimination provision of Title III applies to practices falling outside this narrow protection. Disability-based insurance distinctions not based on actuarial data, and thus not based on traditional risk classification, are prohibited in the same way as other forms of disability-based discrimination. Courts and plaintiffs' lawyers should adopt this reading of section 501(c) as the best route to establishing a risk basis rule for nondiscrimination in insurance under Title III and should avoid the "subterfuge" route to this rule.

\section{Actual or Reasonably Anticipated Experience: An Uncharted Issue}

The notion of "actual or reasonably anticipated experience" that appears in the legislative history presents plaimtiffs' lawyers with a problem. The arguinent $I$ have just presented is an argument for inferring the requirement of actuarial data from the underwriting-and-classifying language of section 501(c). There is no reason, under my argument, why we should rely on the language "based on sound actuarial principles or related to actual or reasonably anticipated experience" that appears in the legislative history. The text of the statute itself supplies the actuarial data requirement, so this secondary source is unnecessary. Furthermore, the

214. For citations to such bills introduced between 1979 and 1985 , see Wortham, supra note 207, at 364 n.59.

215. For citations to hearings on these bills, see id. at $355 \mathrm{n} .26$.

216. See supra note 202 . 
phrase "actual or reasonably anticipated experience" threatens to undermine the actuarial data requirement, because, unlike the underwriting-andclassifying language, this phrase has no particular connection with conventional insurance practices. Therefore, the phrase "actual or reasonably anticipated experience" becomes a weakness for plaintiffs' lawyers, who therefore have reason to wish to jettison the language of the legislative history.

It cannot easily be set aside, however, as the formulation has become curiously ubiquitous. It originated in 1979, during the insurance classification controversy, as a model regulation adopted by the National Association of Insurance Commissioners (NAIC), ${ }^{217}$ and has been adopted as antidiscrimination law in the disability context in a number of states. ${ }^{218}$ The popularity of this formulation at the time of the ADA's drafting undoubtedly proinpted the ADA's sponsors to put it in the legislative history, ${ }^{219}$ and the EEOC ${ }^{220}$ and Department of Justice ${ }^{221}$ to put it in their regulations. Even courts that avoid the "subterfuge" quagmire are therefore likely to view the formulation as a resource for giving precise meaning to the underwriting-and-classifying language. Plaintiffs' lawyers therefore need an interpretation of "actual or reasonably anticipated experience" that will not destroy the requirement of statistical data.

One district court has demonstrated the danger of destroying the statistical data requirement in a case in which the plaintiff had been denied mortgage disability msurance because she had bipolar disorder. In Doukas v. Metropolitan Life Insurance Co., ${ }^{222}$ the defendant insurance company apparently had not supplied actuarial data showing increased risk for this type of insurance where the insured had bipolar disorder. ${ }^{223}$ Relying on the theory that the ADA prohibits disability-based insurance decisions that are not based on actuarial data, the plaintiff argued that if the insurer could put nothing into evidence to demonstrate that its decision was based on actuarial data, there would be no disputed issue of material fact to take to trial. Accordingly, the plaintiff moved for summary judgment. ${ }^{224}$ The court held that "the ADA would not require that an insurance company base

217. See Model Regulation on Unfair Discrimination in Life and Health Insurance on the Basis of Physical or Mental Impairment, Section III, 1979 Proc. Nat'l Ass'n Ins. Commissioners, Vol. II, at 262.

218. See Farber, supra note 169 , at $869 \mathrm{n} .99$, for citation of statutes of 17 states similar to the NAIC model regulation. The NAIC itself reports only 10 state statutes similar to the model regulation. See Model Regulation, supra note 213.

219. See H.R. REP. No. 101-485(III), at 71 (1990), reprinted in 1990 U.S.C.C.A.N. 445, 493, 494; see also S. REP. No. 101-116, at 84-86 (1989).

220. EEOC Interim Guidance on Application of ADA to Health Insurance, supra note 19, at D22.

221. See 28 C.F.R. pt. 36, app. B at 612-13 (1995).

222. 950 F. Supp. 422,424 (D.N.H. 1996).

223. See id. at $428-30$.

224. See id. at 424. 
its insurance decisions on actuarial principles; instead, the ADA also permits such decisions to be related to actual or reasonably anticipated experience."225 Therefore an issue of material fact-whether the decision was related to such experience-was present, and the motion was denied. ${ }^{226}$

This court's holding suggests a meaning for the expression "actual or reasonably anticipated experience." The evidence on which the court found a disputed issue of material fact indicates the sort of ground on which imsurers and insureds might fight out the question whether or not a disability-based decision is based on such experience where the insurer does not have actuarial data. The company presented an affidavit by one of its underwriters stating that the company's "experience as an insurance carrier has demonstrated increased inorbidity among those applicants suffering from bipolar disorder, as well as a trend of longer disabilities for those diagnoses as compared to other impairment groups."227 This inay be seen to allege both actual experience of increased risk and a reasonable basis to anticipate greater-than-standard claims in the particular case. Against this evidence, the planitiff submitted a medical expert's affidavit describing "certain 'prognostic indicators' that can be used to distingnish high-risk patients from low-risk patients," and that the high-risk patients are "those who had not received treatment, have not complied with a treatment regimen, or have abused alcohol or other substances." 228 Because she was not in one of these high-risk categories, the plaintiff argued, her risk was "nearly the same as that of a meinber of the general population."229 The court denied the defendant's summary judgment motion as well as the plaintiff s. ${ }^{230}$ This suggests that two kinds of evidence were probative of the existence of actual or reasonably anticipated experience in the absence of statistical data: the insurance company's own experience of the results of selling policies to people with the plaintiff's condition, and expert testimony for the plaintiff about nonstatistical risk-reducing factors the company could have considered but did not. Thus Doukas goes some distance toward showing how an insurance company lacking actuarial data might have a defense under the experience clause and how a plamtiff might attack it.

Prudent plaintiffs' lawyers should thus, where possible, present some positive evidence that the plaintiff does not present an increased risk, in a situation in which the insurance coinpany might be able to show increased risk on some basis other than actuarial data, or might be able to show that actuarial data are unavailable to it. But the result in Doukas shows that,

225. Id. at 428.

226. See id. at 430,432 .

227. Id. at 429.

228. Id. at 430.

229. Id.

230. See id. at 432 . 
even in a court that recognizes coverage of insurance by Title III, an insurance company might be able to satisfy the requirements of section 501(c) by producing something that might count as evidence of experience.

\section{CONCLUSION}

The No-Law position on section 501(c) and the physical-access interpretation of section 302(a) are the two obstacles for plaintiffs suing insurers under the ADA. The physical-access interpretation of section 302(a) would place insurance discrimination outside Title III's coverage, along with all other forms of discrimination not involving ability to make use of a physical facility. This interpretation conflicts with long passages of the ADA's text prohibiting specific forms of discrimination that have no special connection with ability to make use of a physical facility and prohibiting discrimination against classes of people who would receive no protection under such a rule. It also conflicts with the ADA's general purposes. The physical-access interpretation also leads to the conceptual anomaly that an insurance policy admitted to be a good or service, which comes from an admittedly physical insurance office, is not a good or service of a physical place. This anomaly lies behind the defects of the court's arguments in Parker v. Metropolitan Life Insurance Co.

The No-Law position would exempt insurers from regulation by Title III altogether. But No-Law is not a viable reading of section 501(c) because the accepted meaning of the concept of underwriting and classifying insurance risks and the historical background against which Congress incorporated that concept into the ADA tie section 501(c) to the tradition of grouping like risks together. Therefore the Risk-Basis position is the correct one. Some courts, administrative agencies, and commentators reach this result by the wrong path: a strained interpretation of the "subterfuge" clause. The result is reachable by a path of much lower resistance: reference to the accepted meaning of underwriting and classifying risks. It is important for the future of the Risk-Basis doctrine that this more amenable path be followed.

The future of disability law depends on the ability of plaintiffs' lawyers to convince courts not to permit narrow interpretations of the ADA's language to defeat the greater ambitions Congress expressed in stating the ADA's purposes. The Supreme Court has begun down two tracks simultaneously, allowing such narrow interpretations to prevail in some cases ${ }^{231}$ and giving effect to the statute's broad aims in others. ${ }^{232}$ The question of

231. See Sutton v. United Air Lines, 119 S. Ct. 2139 (1999) (holding that termination of employment because of disability is permissible under the ADA if the disability is corrccted by a mitigating measure); Murphy v. United Parcel Serv., 119 S. Ct. 2133 (1999) (same).

232. See Olmstead v. L.C., 119 S. Ct. 2176 (1999) (holding that, where appropriate, mentally disabled patients of state hospitals were entitled under the ADA to nonsegregated, community based 
how to interpret sections 302(a) and 501(c) is part of this larger dynamic, and it is a part that affects all people with disabilities who rely on any type of insurance. That plaintiffs' positions on these two issues should prevail is thus crucially important to the future of ineaningful enforcement of the $\mathrm{ADA}$ in the area of public accommodations.

treatment); Cleveland v. Policy Management Sys., 119 S. Ct. 1597, 1601 (1999) (holding that a terminated employee who had claimed Social Security Disability benefits was not, for that reason, estopped from advancing an ADA claim). 
